\title{
Income inequality and export prices across countries *
}

\author{
Lisandra Flach ${ }^{\dagger}$ \\ University of Munich
}

\author{
Eckhard Janeba ${ }^{\ddagger}$ \\ University of Mannheim
}

February 2015

\begin{abstract}
This paper provides first firm-level evidence on the links between income inequality within a destination country and the patterns of trade and export prices. We identify a theoretical mechanism behind these links, which relates income inequality to product quality and prices using a simple demand composition effect. Theory suggests that a more unequal distribution of income in a country leads to higher average prices, though the effect is non-linear and disappears for countries exceeding a certain level of income. The predictions are confirmed using detailed firm-level data. Controlling for income per capita, prices are systematically higher in more unequal destination countries, and the strength of this effect depends on income per capita. Our results are robust to different measures of income inequality, hold only for differentiated goods and in particular for products with a high degree of vertical differentiation.

Key-words: exports prices, income distribution, product quality, markups.

JEL classification: F12, F14, L11.
\end{abstract}

${ }^{*}$ We thank Eddy Bekkers, Carsten Eckel, Peter Eppinger, Hannes Kammerer, Hélène Latzer, Kalina Manova, Marc Muendler, Monika Schnitzer, Emanuel Ornelas, Alexander Tarasov, Gonzague Vannoorenberghe and the participants of the Midwest International Economics Group (MI-USA), ETSG-Birmingham, LACEA/LAMES Sao Paulo, Göttingen International Economics Workshop and seminars in Mannheim and Munich for helpful comments.

${ }^{\dagger}$ Department of Economics, University of Munich. Ludwigstrasse 28, 80539 Munich, Germany. Email: Lisandra.Flach@econ.lmu.de

${ }^{\ddagger}$ Department of Economics, University of Mannheim. L7, 3-5, 68131 Mannheim, Germany. Email: janeba@uni-mannheim.de 


\section{Introduction}

The relation between income per capita on the one hand and consumption and trade patterns on the other hand has attracted a lot of attention in the international trade literature. Virtually every empirical paper studying trade prices predicts a positive relation between a country's income per capita and average trade prices, suggesting that high-income countries consume and produce goods of higher quality. ${ }^{1}$ This literature goes back to the Balassa-Samuelson effect, first introduced in 1964 (Balassa (1964) and Samuelson (1964)), showing that consumer prices are systematically higher in richer countries. Yet income per capita might not fully explain the patterns of trade and prices in some economies. Mitra and Trindade (2005) investigate the impact of income inequality on trade flows. Fajgelbaum, Grossman, and Helpman (2011) and further recent studies strongly suggest that income inequality within a country matters for trade patterns and pricing of traded goods. ${ }^{2}$ While the effect of consumption and trade on income distribution has been widely investigated, we are interested in this reverse channel. Does income inequality within a destination matter for consumption patterns and export prices across destinations? This channel has not been given much attention in the empirical literature (which is discussed in section 2).

Understanding the above channel is important because it allows economists to better predict the patterns of trade (in terms of quality differentiation) and prices of goods, and thereby contribute to our understanding of the international ramifications from economic development. Income inequality is rising in many countries, either because the number (or wealth) of rich individuals is increasing, and/or because the poor are falling behind. ${ }^{3}$ For instance, China has experienced a tremendous increase in per capita income over the last decades. This tends to lead to higher demand for high quality goods and thus higher prices of imported goods. Simultaneously, China's distribution of income has become much more unequal, driven in part by an increase in the number of rich individuals (Chen and Ravallion 2007). Changes in income inequality could decrease or increase product prices and demand for quality, depending on how the quantity and quality in different consumption categories change with income inequality. Hence the net effect from rising income inequality is a priori unclear.

\footnotetext{
${ }^{1}$ Hummels and Klenow (2005) and Hallak (2006) show that prices increase with exporter and importer income per capita, respectively, and suggest that countries with higher income produce and consume products of higher quality. Similar evidence is found at the firm-level (see Manova and Zhang (2012) and Bastos and Silva (2010)), and using a structural approach as Khandelwal (2010) and Hallak and Schott (2011).

${ }^{2}$ Fajgelbaum, Grossman, and Helpman (2011) derive conditions under which a richer, or more unequal, country has a larger demand for high quality goods. They provide a demand-based explanation for the patterns of trade in goods of different quality.

${ }^{3}$ Poverty has fallen since 1981 in many countries in Latin America, the Middle East and North Africa, but not enough to reduce the total number of poor (Chen and Ravallion 2007). Income inequality has also risen in most OECD countries, as shown by a recent report from OECD (2011).
} 
This paper provides first firm-level evidence on the links between income inequality and the patterns of trade and export prices, and identifies a theoretical mechanism behind these links. We show that more income inequality in a destination country leads to higher average prices of traded goods, and the strength of this effect depends on average income. To guide empirical work, we present a theoretical framework based on a simple demand composition effect. Assuming a simple form of non-homothetic preferences and linear technology, only individuals above a certain income threshold choose among a continuum of differentiated products, while very poor individuals can afford only consumption of necessities (i.e. a numeraire good). This result implies that the quality demanded is a (weakly) convex function of income and thus the distribution of income matters for the average price. Intuitively, when some individuals from the middle class become poor while others become rich, and thus inequality increases, only the demand of the newly rich for the differentiated good matters and thus the average price goes up. In particular, we show that the mechanism is at work when income is Pareto distributed. There exists a positive correlation between income inequality and average price (for given average income). Further results from the model reveal that the mechanism is particularly likely to operate for middle income countries where poor individuals (who consume only the numeraire good) and rich individuals live at the same time.

Our empirical results are based on detailed firm-level data with information on export prices by firm, product and destination countries, which is combined with several measures of income inequality of the destination country. Our results suggest that prices are systematically higher in more unequal destination countries, and this effect is always significant for middle-income countries and always disappears for very rich countries. Additional results reinforce the predictions from our theoretical model. First, results hold only for differentiated goods and in particular for products with high degree of differentiation (using a continuous measure of product differentiation). For the control variables, while results for differentiated goods may be reconciled with heterogeneous firms models with quality differentiation such as Baldwin and Harrigan (2011), results for homogeneous goods are consistent with efficiency sorting models such as Melitz (2003), which reinforce our findings. Second, we present results using product fixed effects as well as firm-product fixed effects. In both cases, results reveal that prices are systematically higher in more distant, richer, and more unequal destination markets. Third, our findings are robust to different measures of income inequality and not driven by selection into destinations.

In addition, and in line with the predictions from our theoretical model, we show that the effect disappears for rich enough countries. Moreover, results are always significant for middle-income countries. Middle-income countries experienced several changes in the compo- 
sition of income groups in the last years and an increase in the number of rich individuals. As discussed in Dalgin, Mitra, and Trindade (2008), when the income expansion path is curved, income distribution becomes a determinant of aggregate demand. In this case, rich individuals buy proportionately more high quality goods. Moreover, firms may charge even higher markups for these goods: When individuals get wealthier, they are willing to pay more for high quality goods.

The use of product prices to explain consumption patterns under non-homothetic preferences and differences in product quality is not novel in the literature. Yet, we show for the first time empirical evidence at the firm level of the importance of income inequality within a country for trade patterns, and find a theoretical link that explains this empirical fact. Data at the firm level have several advantages over data aggregated at the country level. Using firm-level data, we are able to use a high level of product disaggregation, to track firm behavior, and to control for any supply-side unobserved heterogeneity not related to product quality or markups. ${ }^{4}$ Moreover, using export data instead of import data to explain demand in the destination market has the additional advantage of relying on f.o.b. (free on board) prices. Different from c.i.f. (cost insurance and freight) prices, which contain transportation costs and several other costs not related to production costs and markups, the use of f.o.b. prices allows us to deal with several concerns regarding price measurement.

\section{Related Literature}

Our paper is related to a large literature on export prices and destination country characteristics. Many of these studies find a strong positive relationship between prices and the country's income per-capita (Hallak 2006, 2010; Hummels and Skiba 2004; Hummels and Klenow 2005), and attribute higher prices to higher quality. Our findings confirm these results and provide evidence for further moments of the income distribution.

Our paper is also related to a sizable theoretical literature on non-homothetic preferences and vertical product differentiation. Flam and Helpman (1987) study consumption and trade patterns in a North-South model with vertical differentiation, in which household income maps to product quality choice. On the production side, producing higher quality requires higher costs and, on the demand side, consumers with higher income choose products with higher quality and therefore higher costs. Fajgelbaum, Grossman, and Helpman (2011) de-

\footnotetext{
${ }^{4}$ Prices aggregated to the country level might fog important unobserved characteristics related to the firm and product that are not related to the quality of the good or to markup pricing. Moreover, the analysis of prices across countries instead of across firms may be an important source of measurement error, since quantities are collected by different customs and may be reported in different units, which is not the case of the firm-level data, subject to a unique regulatory system.
} 
velop a model in which quality rises in income and generate home market effects that help explain why richer countries export products of higher quality. In contrast to these papers, we do not assume that all consumers necessarily buy from the set of differentiated goods. Mitra and Trindade (2005) also offer a demand-side explanation for the patterns of trade using nonhomothetic preferences. However, they show that gains from trade are due to specialization in consumption, not in production. Also using non-homothetic preferences, Markusen (2013) discusses home bias in consumption and the role of intra-country income distribution. ${ }^{5}$

Empirically, Choi, Hummels, and Xiang (2009) examine a version of the Flam and Helpman (1987) model.They find that countries with more similar income distributions have more similar import price distributions. There are two main differences in their study in comparison to ours. First, they use world imports to investigate whether countries with similar income distributions have more similar import price distributions, while we study the direct relation between export prices and inequality of the destination country. ${ }^{6}$ Second, the source of price variation within a destination country in Choi, Hummels, and Xiang (2009) is the sourcing country, whereas our source of variation is the sourcing firm using f.o.b. prices. ${ }^{7}$

On the side of the destination country, and closest to our study, Bekkers, Francois, and Manchin (2012) investigate the predictions from three different theories using the effect of income inequality on prices. They find empirical support for the hierarchic demand model and contradict the quality and ideal variety theories. As individuals become richer, more goods become indispensable, which decreases the price elasticity of these goods and raises markups. Through the reduction in the price elasticity, trade prices decrease with income inequality. These empirical results differ from models incorporating demand for quality, such as Fajgelbaum, Grossman, and Helpman (2011), who show that, under certain conditions, richer or more unequal countries have a larger demand for high quality goods. Bekkers, Francois, and Manchin (2012) suggest that their results do not falsify the quality theory, but rather show that markups explain a great part of the variation in prices. They also provide a quality model that relates to our theoretical mechanism. Firms may produce different quality for each income group, since there is perfect competition and no fixed production costs. They show that, for utility increasing both in quality and quantity, more inequality leads to higher prices. This is the same prediction from our theory, though in our case not all individuals consume the differentiated good, which implies non-linearities. On the side of the home coun-

\footnotetext{
${ }^{5}$ The role of intra-country income distribution is also discussed by Yurko (2011) in a model in which income inequality leads to more competition and quality differentiation.

${ }^{6}$ This allows us to control for several country, product, market and firm characteristics. Moreover, we are rather interested in how inequality affects price patters (not price similarity).

${ }^{7}$ There are two main advantages of using firm-level data for one single country. First, aggregate data may be subject to measurement error, for instance because countries report import and export quantities in different ways. Second, we rule out all sourcing country unobserved characteristics not related to quality.
} 
try, Latzer and Mayneris (2012) study the effect of income inequality in the sourcing country on the patterns of trade and find a positive effect only for rich enough countries.

At the aggregate level for trade flows, Francois and Kaplan (1996) have shown that the income distribution, and in particular income inequality, has an important effect on trade flows. Dalgin, Mitra, and Trindade (2008) use a gravity approach and show that the difference in import demand for luxuries versus necessities varies with income inequality. These results are in line with our empirical results using firm-level trade prices.

Concerning the literature using firm-level data, our paper is related to a rapidly growing literature on the firm-level sources of price variation across destinations (Bastos and Silva 2010; Martin 2012; Manova and Zhang 2012; Kugler and Verhoogen 2012).Our empirical analysis confirms to a large extent the results from this literature and show novel results for income inequality. On the demand side, Di Comite, Thisse, and Vandenbussche (2014) introduce a verti-horizontal model with heterogeneous consumers across countries and heterogeneous tastes within a country. One interesting feature is that firm-product-country exports can be idiosyncratic and lead to additional variability even controlling for firm-product specific productivity and demand shifters, which nicely relates to our within-firm results. Finally, our paper is also related to a literature suggesting that firms adjust product quality and/or markups to high-income destinations. ${ }^{8}$

\section{Model}

We consider a small open economy with two goods, a homogenous good and a differentiated good. The latter comes in a continuum of varieties/qualities $z \in\left[z^{-}, z^{+}\right]$, with $0 \leq z^{-}<$ $z^{+}<\infty$, where a higher value of $z$ is interpreted as higher quality. We assume that prices are set in the world market. The homogenous good is produced under constant returns to scale using labor as the only input, which is the numeraire and whose price is normalized to one. The price of the differentiated good of quality $z$ is $p(z)$. In particular, we postulate that the price function for quality follows:

$$
p(z)=\alpha z, \alpha>0
$$

Behind condition (1) is the assumption that the differentiated good is produced under constant returns to scale and is sold in a perfectly competitive market. Later we discuss an extension of the model by introducing horizontal product differentiation in addition to the (vertical)

\footnotetext{
${ }^{8}$ For instance, Verhoogen (2008) and Flach (2014) on quality and Simonovska (2013) on markups.
} 
quality dimension and assume that goods are produced in a monopolistic competitive market environment. Condition (1) implies a positive correlation between price and quality. To simplify matters we assume also that the economy produces only the numeraire good, which is exported, and imports the differentiated good (but later we briefly discuss general equilibrium effects and endogenous trade patterns). We abstract from trade costs.

The economy is inhabited by a continuum of individuals who share identical preferences but differ in their skill. The latter is described in more detail below. The population size is normalized to one. An individual has preferences over the numeraire good and the differentiated good. We assume that the individual buys either one unit of the quality differentiated good or abstains from buying. She may purchase any number of the homogenous good. The option of not buying the quality differentiated good is a crucial feature of our model. To illustrate how the main mechanism works we postulate the following simple utility function

$$
u=c(1+\delta z)
$$

where $c$ is the number of units of the homogenous good, $z$ is the quality of the differentiated good, and $\delta$ is a dummy variable taking the value of one if the individual buys the differentiated good and zero if not. The multiplicative structure displayed in (2) builds on the work by Fajgelbaum, Grossman, and Helpman (2011), who also assume complementarity between the numeraire good and the quality of the differentiated good. Our work differs from theirs by allowing for the case in which income of some consumers is too small to buy the differentiated good. This aspect is crucial for our subsequent results.

Letting $y$ refer to income, the budget constraint of a consumer can be written as

$$
c+\delta p(z) \leq y \text {. }
$$

Conditions (2) and (3) have immediate implications. Assume for the moment that the differentiated good is purchased (which we verify ex post). Since (3) is binding, we can formulate the utility maximization problem by inserting (3) into (2) and derive the first order condition for the optimal choice of quality:

$$
-(1+z) p^{\prime}(z)+y-p(z)=0 .
$$

Given the linear pricing relationship (1), the second order conditions holds, and the solution to (4) reads

$$
z=\frac{y-\alpha}{2 \alpha}
$$


Expression (5) is the correct representation of the optimal quality if income is not less than $\alpha$ and the proposed quality is actually offered in the market. We assume $z^{-}=0$, which implies that (5) is feasible (in the sense of being offered in the market) when $y \geq \alpha$. Moreover, in this case (5) indicates the global utility optimum. An individual who purchases the differentiated good pays $p(z(y))=(y-\alpha) / 2$, has private consumption $c=(y+\alpha) / 2$, and therefore obtains indirect utility $v=(y+\alpha)^{2} / 4 \alpha$. The utility level is indeed higher than not purchasing the differentiated good, which is identical to buying the differentiated good with quality 0 , and leads to private consumption and indirect utility $v=c=y$. Note that indirect utility is continuous at the threshold income level $y=\alpha$.

We thus summarize the optimal consumer choice of the differentiated good as follows:

$$
z^{*}=\left\{\begin{array}{cc}
\frac{y-\alpha}{2 \alpha} & \text { if } y \geq \alpha \\
0 & \text { if } y<\alpha .
\end{array}\right.
$$

Condition (6) implies that the relationship between demand for quality and income is (weakly) convex.

The production of the numeraire good is using labor as only input and exhibits constant returns to scale. This implies that the wage per unit of labor is unity. Individuals differ in their skill level which is described in effective units of labor. The combination of fixed skill levels, exogenous labor supply and unit wages allows us to move directly to the income distribution. We use the notation $F(y)$ for the cumulative income distribution function, for $y \in[\underline{y}, \bar{y}]$, and $f(y)$ as its density.

We now want to analyze the relationship between the income distribution and the average price of the (imported) differentiated good. Let $Y$ be the average (and total) income, and $Y_{\alpha}$ be the average income of all individuals above the threshold $\alpha$ (i.e., the truncated income distribution). Assuming $\alpha<\bar{y}$, so that at least some individuals buy the differentiated good, the average price of the imported differentiated good is

$$
P=\frac{\int_{\max \{\alpha, \underline{y}\}}^{\bar{y}} p\left(z^{*}(y)\right) \cdot f(y) d y}{1-F(\alpha)}=\left\{\begin{array}{cc}
\frac{Y_{\alpha}-\alpha}{2} & \text { if } \alpha>\underline{y} \\
\frac{Y-\alpha}{2} & \text { if } \alpha \leq \underline{y} .
\end{array}\right.
$$

Condition (7) makes clear that the average import price of the differentiated good is higher the larger is the average income of those who buy the differentiated good.

Our interest lies in relating income inequality, which is observable and measured for many countries, to the average import price. If we knew $Y_{\alpha}$ for each product, we could proceed 
directly. However, the threshold is not observable at the product level. Our goal is therefore to relate income inequality to the average import price without knowledge of the threshold. Still, we argue below that society's average income may be an important parameter that drives the outcome whether all, some or no individuals are below the threshold.

Consider first the two extreme cases in which either all individuals in a society are below the threshold, that is $\alpha>\bar{y}$, or all individuals are above the threshold, i.e., $\alpha<\underline{y}$. In the former case, our model has nothing interesting to say. In fact, there is no trade because individuals are too poor to buy the differentiated good. By contrast, in the second case all individuals consume the differentiated good (and thus trade occurs). We think about the latter situation as a rich country where average income is very high and individuals regularly consume sophisticated products. Condition (7) implies immediately the following result.

Proposition 1. Consider a rich country where all individuals buy the differentiated good $(\underline{y}>\alpha)$. The average import price of the differentiated good is invariant to changes in income inequality for given mean income.

Under the assumption of Proposition 1 the relationship $Y=Y_{\alpha}$ holds and therefore the average price is unaffected by income inequality, according to (7). This result becomes also clear from inspection of (6), which makes quality demanded a (weakly) convex function of income. If every individual is above the threshold, the relationship between $z$ and $y$ is linear. Hence for a given average income level the distribution of income is immaterial. The convexity arising from the option to not purchasing the differentiated good is the key factor in our model and differentiates it from the rest of the literature. ${ }^{9}$

Next we move to the interesting case where at least some but not all individuals are above the threshold, that is $\underline{y}<\alpha<\bar{y}$. This case may be particularly relevant for middle income and moderately poor countries. With the help of a simple example we suggest that larger income inequality correlates with a higher average import price.

Example 1. Consider two different income distributions, $i=1,2$, with uniform density $f^{i}(y)=\left(\bar{y}^{i}-\underline{y}^{i}\right)^{-1}$, which differ in the maximum and minimum income but share the same average income $Y$. Assume furthermore that at least for one (say, the first) distribution some but not all individuals are under the threshold: $\underline{y}^{1}<\alpha<\bar{y}^{1}$. Using (7), average income above the threshold $\alpha$ is given by

$$
Y_{\alpha}^{1}=\frac{\bar{y}^{1}+\alpha}{2},
$$

\footnotetext{
${ }^{9}$ For example, in Flam and Helpman (1987) the demand for quality is concave in income, given the specification of preferences and technology. Consumers always consume the differentiated good and the focus is on the pattern of specialization across countries.
} 
and thus determines average price. We must consider two cases concerning distribution 2: i) If $\alpha<\underline{y}^{2}$, average income for distribution 2 is $Y$, which is less than $\frac{\bar{y}^{1}+\alpha}{2}$ because $Y=\frac{\bar{y}^{1}+\underline{y}^{1}}{2}=\frac{\bar{y}^{2}+\underline{y}^{2}}{2}$. Clearly, the support of distribution 2 is smaller given equal average income and $\underline{y}^{1}<\alpha<\underline{y}^{2}$. Hence the variance of incomes under distribution 2 is smaller than for distribution 1. ii) If $\alpha>\underline{y}^{2}$, average income above the threshold is given by $Y_{\alpha}^{2}=\frac{\bar{y}^{2}+\alpha}{2}$. Comparing $Y_{\alpha}^{1}$ and $Y_{\alpha}^{2}$, the situation with more unequal incomes (due to the more extreme values of the maximum and minimum income) translates into higher average income above the threshold and thus has the higher average price. ${ }^{10}$

Example 1, while simple and intuitive, is special because the uniform density assumption is restrictive. The next result shows that the positive correlation between income inequality and average import price holds for an important distribution function, namely the Pareto distribution, for which the cumulative distribution function can be written

$$
F(y)=1-(\underline{y} / y)^{k}, \text { for } y \geq \underline{y},
$$

and zero else, where $y$ is the minimum income level (the scale or location parameter) and $k>1$ is the shape parameter. For this distribution the mean income is given by

$$
Y=\frac{k \underline{y}}{k-1}
$$

and inequality measured by the Gini coefficient is ${ }^{11}$

$$
G=\frac{1}{2 k-1}
$$

We can now state the following result for Pareto distributions.

Proposition 2. Consider two income distributions $(i=1,2)$ that are Pareto distributed with the same mean income $Y^{1}=Y^{2}$, but with different scale $\underline{y}^{i}$ and shape parameters $k^{i}$. Assume furthermore that for both distributions the condition $\underline{y}^{i}<\alpha<\bar{y}^{i}$ holds. The society with the more unequal income distribution measured by the Gini coefficient has the higher average import price.

\footnotetext{
${ }^{10}$ In Example 1 inequality is measured by the variance of incomes. The results of Example 1 go through if we measure inequality by the Gini coefficient, which for the uniform density of incomes is given by $\frac{\left(\bar{y}^{i}-\underline{y}^{i}\right)}{3\left(\bar{y}^{i}+\underline{y}^{i}\right)}$.

${ }^{11}$ See, for example, Lubrano (2013).
} 
Proof: Given (9) the equal means condition requires

$$
Y^{1}=\frac{k^{1} \underline{y}^{1}}{k^{1}-1}=Y^{2}=\frac{k^{2} \underline{y}^{2}}{k^{2}-1}=Y
$$

which removes one degree of freedom in choosing the four parameter values $\left\{k^{1}, k^{2}, \underline{y}^{1}, \underline{y}^{2}\right\}$. Hence we are free to choose the shape parameters $k^{i}$ when one of the location parameters is endogenous to satisfy the equal means condition.

From the definition of the Gini coefficient (10) it is clear that the distribution with the lower level of $k$ is the more unequal one. In order to link inequality to average price we now need to consider the truncated income distribution, where the cutoff is $\alpha$. A well known feature of the Pareto distribution is that the truncated distribution is also Pareto distributed. The mean income of the truncated distribution is

$$
Y_{\alpha}^{i}=\frac{k^{i} \alpha}{k^{i}-1}
$$

Hence the distribution with the lower level of $k$ has the higher average income level above the threshold and thus the higher average price. To finalize the proof we need to relate to the Gini coefficient of the truncated income distribution. Theorem 3 of Ord, Patil, and Taillie (1983) proves that the Gini coefficient of the Pareto distribution is invariant to any truncation from the left. Hence, we may conclude that the distribution with more unequal incomes in the original distribution is also the one which is more unequal under truncation with threshold $\alpha$. This completes the proof.

Proposition 2 is a powerful result in so far as it links the inequality measure of the original income distribution to the average income of the truncated distribution. Theorem 3 of Ord, Patil, and Taillie (1983) establishes the crucial step for the proof. Unfortunately, the same theorem shows as well that the invariance result holds only for the Pareto distribution. Therefore there is no hope to apply the logic to other distributions.

The Pareto distribution underlying Proposition 2 carries a special implication. Condition (11) shows that the mean income of the truncated distribution is independent of the average income of the original distribution, and depends only on the threshold parameter and the shape parameter. This implies that the average price of the imported good should not differ across countries with different average incomes (for given threshold and inequality levels). We evaluate this property in our empirical analysis where we control for income per capita.

We like to emphasize the role played by the assumption that under both income distributions some individuals have incomes below the consumption threshold $\alpha$. In this case the 
ranking of the average import price $\left(P^{1}\right.$ vs. $\left.P^{2}\right)$ is related to the ranking of average incomes above the threshold $\left(Y_{\alpha}^{1}\right.$ vs. $\left.Y_{\alpha}^{2}\right)$. Because the latter depend only on the common threshold $\alpha$ and the shape parameters $k^{1}$ and $k^{2}$, we can link the ranking of average incomes above $\alpha$ directly to the ranking of the Gini coefficients ( $G^{1}$ vs. $G^{2}$ ), which depend only on $k^{i}$. By contrast, if only one income distribution has individuals below the threshold, we cannot link unambiguously the ranking of average incomes above the threshold to the shape parameters $k^{i}$ because now the thresholds differ across income distributions ( $\alpha$ vs. $\underline{y}$ ). Hence the chain of proof is interrupted.

More can be said, however, when in the comparison of the two income distributions the lowest income of one and only one distribution is below the threshold. Compare two income distributions, $i=1,2$, with the same mean income $Y^{1}=Y^{2}$, which differ in terms of the range of actual incomes at the lower end. The first distribution $F^{1}(y)$ has some consumers having income less than $\alpha$, so that $\underline{y}^{1}<\alpha$. The second distribution $F^{2}(y)$ has a relatively high level of the lowest income: $\underline{y}^{2} \geq \alpha$, so that all individuals purchase the differentiated good. These distributional assumptions correspond to case i) in Example 1. We do not make any further assumptions on the income distributions.

Proposition 3. Compare two societies which share the same mean income but only one has individuals below the threshold $\alpha$. The society with individuals below the threshold $\alpha$ has a higher average import price of the differentiated good.

Proof: We need to show that $Y_{\alpha}^{1}>Y^{2}=Y$, that is, the average income of those who purchase the differentiated good is higher under the first income distribution. In this case, using (7), the average price under the first distribution is higher $\left(P^{1}>P^{2}\right)$ than under the second one. We start with the observation that $Y>Y_{\alpha^{-}}^{1}$, where $Y_{\alpha^{-}}^{1}=\int_{y^{1}}^{\alpha} y f^{1}(y) d y / F^{1}(\alpha)$ is the average income of individuals below the threshold under distribution 1 . The inequality must hold because by assumption $Y=Y^{2}=Y^{1}$ and all individuals under distribution 2 are above the threshold. Using the observation and the definition of $Y_{\alpha^{-}}^{1}$ we obtain

$$
\begin{aligned}
Y & >Y_{\alpha^{-}}^{1} \\
& \Longleftrightarrow-F^{1}(\alpha) Y_{\alpha^{-}}^{1}>-F^{1}(\alpha) Y \\
& \Longleftrightarrow Y-\int_{\underline{y}^{1}}^{\alpha} y \cdot f^{1}(y) d y>Y\left(1-F^{1}(\alpha)\right),
\end{aligned}
$$


which in turn is equivalent to

$$
Y_{\alpha}^{1}=\frac{\int_{\alpha}^{\overline{y^{1}}} y \cdot f^{1}(y) d y}{1-F^{1}(\alpha)}>Y=Y^{2}
$$

This proves the claim.

Proposition 3 differs from the previous results as the former does not relate directly to income inequality (measured by variance or Gini coefficient). Rather we see the result as a link of the average price of imported goods to poverty if we interpret the threshold $\alpha$ as poverty level. In our subsequent empirical analysis we explore this link as well.

The common feature of Propositions 2 and 3 is that at least one of the two distributions under comparison has individuals below threshold $\alpha$. We think that the two Propositions are particularly relevant for middle income countries who experience an increase in inequality when average income is high enough so that many households have means to spend on consumption goods beyond basic food and shelter.

We end the discussion of our theoretical base model with a short remark on the role of general equilibrium effects. Our model is partial equilibrium in nature as prices and the pattern of trade and specialization are exogenously given. These assumptions appear to be strong in the context of a two-country model, where indeed general equilibrium effects are likely to affect the pattern of specialization through price adjustments. Flam and Helpman (1987) provide a good example. The context of our subsequent empirical analysis with many countries in a world economy makes it more plausible to assume that a single country is not the only country producing goods of a particular quality. Countries with similar per capita income may also specialize in differentiated goods of similar quality, and this set may be small relative to the set of all qualities offered in the world market.

\section{Markup Pricing and Firm Heterogeneity}

In the baseline model we assumed that goods are produced under constant returns to scale and markets are perfectly competitive. Prices thus reflect marginal cost. Extending the model to allow for some sort of market power is important because in our empirical analysis we need to control for markups in pricing, which themselves might be driven by inequality. Below we outline two ways for incorporating a monopolistic competition framework and thus markups into the above analysis. Both of them leave the basic mechanism underlying the results in Prop. 1-3 unaffected. Our empirical analysis also reveals differences in markups across firms. The second approach that we discuss below allows for differences in firm productivity and thus introduces firm heterogeneity into the base model on top of markups due to imperfect 
competition.

The first approach follows the idea of Fajgelbaum, Grossman, and Helpman (2011). All individuals are in a position to purchase the differentiated good, which at each quality level comes in several varieties. Extending our base model now, a good of a given quality is offered in different varieties by monopolistically competitive firms, where each firm produces a single variety after paying a fixed cost for developing the particular variety. There is free entry of firms but the number of firms is constrained by the zero profit condition. Individuals have heterogenous preferences over varieties, which are generated by introducing an additive term $\varepsilon$ in utility function (2). This leaves the basic complementarity property between the quality of the differentiated good and the numeraire unaffected. $\varepsilon$ is drawn from a generalized extreme value distribution.

Fajgelbaum, Grossman, and Helpman (2011) show that the profit maximizing price for a firm producing a given quality $z$ is given by

$$
p_{z}=c_{z}+\frac{\theta_{z}}{z}
$$

where $c_{z}$ represents marginal cost and $\theta_{z}$ is a parameter of the generalized extreme value distribution that measures the heterogeneity of preferences over the varieties with a given quality $z$. Larger values of this parameter correspond to lower levels of correlation between the valuations of different varieties. The second factor on the right hand side of (13) is the markup which is increasing in quality $z$ if $\theta_{z}$ rises sufficiently strongly in quality. In this case the markup is larger for higher quality goods, and thus societies which consume on average more high quality goods experience a bigger markup on average. Extending our baseline model along the lines of Fajgelbaum, Grossman, and Helpman (2011) would imply markups increasing in product quality and prices.

The second option, that accounts in addition for firm heterogeneity, is to introduce horizontal product differentiation through a love-of-variety preference structure. Specifically, once individuals choose the unit of the differentiated good of quality $z$, they consume one unit of a CES composite good of differentiated varieties, which are produced by firms in a monopolistically competitive environment. The price in budget constraint (3) is reinterpreted as a price index for the composite good. This approach follows Garcia-Marin (2014), who extends the base model that we presented in an earlier version of our paper (Flach and Janeba 2013) by linking it to a standard monopolistic competition framework in the tradition of Chaney (2008). Garcia-Marin (2014) follows Chaney (2008) by introducing firm productivity $\varphi$ drawn from a Pareto distribution. Firms may operate in one or two quality segments, whereby pro- 
ducing higher quality is more costly. To export a product from country $i$ to country $c$, firms incur a product-specific cost $F$ and a variable iceberg transportation cost $\tau_{i c}$. Profit maximization leads to a markup over variable cost, which depends on the wage rate, trade cost, firm productivity and the consumer's elasticity of substitution between different varieties.

The model generates a link between inequality and the consumption of product quality at the firm level. The productivity threshold varies across destinations and across quality segments: If we consider two countries identical in all aspects but income distribution, in the country with higher inequality firm profits are higher in the high quality segment relative to the low quality segment and the productivity threshold for high quality is lower. Moreover, following consumers' preferences shown in Flach and Janeba (2013), Garcia-Marin (2014) shows that the intensity of these results is inversely proportional to the level of income of the countries, such that for rich enough countries the effect of income inequality disappears, similar to the results across firms shown in Proposition 2.

The predictions within firms derived from this extension are in accordance with the firmlevel empirical results we find. Moreover, the markup is quality specific if we assume that the elastiticty of substitution differs across quality levels. In particular, we obtain rising markups for higher quality goods if the substitution elasticity rises with product quality. Moreover, markups depend on productivity and thus generate variation across firms.

Under both approaches we thus can augment the base model and combine it with a monopolitistic competition framework where markups are positive. While markups are constant for a given quality level, assumptions on the preferences of the individuals (either the parameter of the distribution function for the preference shock or the elasticity of substitution) generate quality dependent markups. Average markups may thus vary with the composition of consumer purchases of the differentiated good. Moreover, it is conceivable that the number of firms in a given quality segment affects the markup through a competition effect and hence inequality may drive markups through firm entry also indirectly. While this aspect is beyond the scope of this paper in terms of the formal modelling, it is important to keep this idea in mind when interpreting the empirical results in the next sections.

\section{Data and descriptive statistics}

\subsection{Brazilian firm-level data}

We use firm-level data for Brazilian manufacturing exporters collected by the Foreign Trade Secretariat (SECEX) to relate product prices to income inequality. The data contains export values $\left(\right.$ Value $\left._{f c g}\right)$ and export quantities $\left(\right.$ Quant $\left._{f c g}\right)$ by firm $(f)$, product $(g)$ and destination 
country $(c)$, which we use to calculate average prices $\left(\right.$ Price $\left._{f c g}=\frac{\text { Value }_{f c g}}{\text { Quant }_{f c g}}\right)$. The precise steps to build the SECEX export data are described in the Appendix.

One important feature of the data is to be uniformly reported in U.S. dollars (USD) free on board (f.o.b.) across all destination countries, which enables a cross-country comparison of unit values. As we show in Table 10, within the product categories available in the data (8-digit products), there is large scope for quality differentiation. For instance, within the 8digit product 63090010 (Articles for apparel) there are men/women/children overcoats,capes, windcheaters, dresses trousers and many others. Thus, f.o.b. prices within firms across destinations may well reflect differences in product quality, as reported by Verhoogen (2008) and Flach (2014).

Firm-level 8-digit products are classified according to the Rauch (1999) (discrete measure $)^{12}$ and the Khandelwal (2010) (continuous measure) classification of goods.

Table 1 shows the variation in prices $\left(\right.$ Price $\left._{f c g}\right)$ in terms of standard deviations across destinations and across firms. The standard deviation of log prices across destinations is on average 0.10 for a firm-product pair $(f g)$. Across firms this variation is much larger $(0.21)$, in accordance with the literature on firm heterogeneity previously discussed. Moreover, the price variation comes mostly from differentiated goods. ${ }^{13}$

\subsection{Country-level variables and world trade data}

Income inequality data: Data on income inequality comes from the UNO-WIDER. ${ }^{14}$ The main variable of interest is the Gini coefficient, Gini $i_{c}$, measured on a scale of 0 to 100 . Additional measures used in the paper include deciles and decile ratios of the income distribution. For the purposes of our study, information on disposable income was preferred, when available (according to a recent study by Aguiar and Bils (2011), consumption inequality has largely tracked income inequality in the last years). Detailed information on the construction of the index is available in the Appendix to this Chapter.

Further control variables: Import demand elasticities $\left(\operatorname{Sigma}_{c, s}\right)$ at the 3-digit HS are estimated for 73 countries by Broda, Greenfield, and Weinstein (2006). Distance to Brazil, Dist ${ }_{c}$, comes from the CEPII - Centre d'Etudes Prospectives et d'Informations Internationales. Data

\footnotetext{
${ }^{12}$ Rauch (1999) uses the 4-digit SITC classification (issued by the United Nations) to aggregate the trade data in three groups of commodities: (i) w, homogeneous (organized exchange) goods: goods traded in an organized exchange; (ii) r, reference priced: goods not traded in an organized exchange, but which have some quoted reference price, as industry publications; and (iii) n differentiated: goods without any quoted price.

${ }^{13}$ Values in Table 1 are smaller than the ones reported in Manova and Zhang (2012), respectively, 0.46 and 0.90 for the variation across destinations and across firms.

${ }^{14}$ United Nations World Institute for Development Economics Research. The data is available at http: //www.wider.unu.edu/research/Database/en_GB/wiid/.
} 
on bilateral imports and exports by SITC2 sector $(s)$ come from NBER-UN yearly bilateral trade data, documented by Feenstra, Lipsey, Deng, Ma, and Mo (2005). ${ }^{15}$ Using trade data, we calculate different measures of market power of Brazilian firms in every destination country. Data on GDP per capita $\left(C G D P_{c}\right)$ comes from the Penn World Table. ${ }^{16}$ Variables are described in Table 9. The main explanatory variables are summarized in Table 2. Countries are divided according to the tertile of the income distribution.

Figure 1 shows the correlation between income per capita and the Gini coefficient. One could cast doubt on the explanatory power of the second moment of the income distribution (if the correlation with income per capita is high, Gini ${ }_{c}$ does not provide much additional information). However, as shown in Figure 1, the correlation between the Gini coefficient and the income per capita is -0.193 for rich countries, and 0.149 for poor countries. This result is not surprising: according to the Kuznets curve (Kuznets 1955), there is a natural cycle of inequality and income per capita, leading to an inverted u-shaped curve (with Gini on the $\mathrm{Y}$-axis and income per capita on the $\mathrm{X}$-axis).

\section{Empirical Analysis}

This section presents the empirical strategy and the main results following the predictions from the theoretical model. First we show results for all countries. Then we evaluate asymmetries across destination countries. Results are reported for products with different degrees of differentiation, within and across firms.

\subsection{Effect of inequality on prices: Homogeneous versus differentiated goods}

Propositions 1 and 2 from the theoretical model suggest that prices increase in income inequality, though the effect disappears for rich enough countries. We first investigate the effect for all countries, and in the next section we show evidence of asymmetries across countries depending on income. We also investigate in the next section the validity of Proposition 3 using information on poverty rates. Results are reported within and across firms, for homogeneous and differentiated goods. Since homogeneous goods do not have scope for quality differentiation, we do not expect significant results for this type of goods.

The mechanism from our theoretical model refers to the effect of inequality on prices across firms (in an extension we discuss firm heterogeneity). Thus, we first evaluate the effect across firms, using the following price variable: price $_{c g}=\frac{\sum_{f} \text { price }_{f g}}{N_{c g}}$, where $N_{c g}$ is the number of

\footnotetext{
${ }^{15}$ The NBER-UN data uses the Standard International Trade Classification (SITC 2 - Division), 4 digits.

${ }^{16} \mathrm{PWT}$ version 6.2, which uses the year 2000 (the same year of the firm-level data) as the base year.
} 
firms selling product $g$ in country $c$ and price $_{c g}$ is the average price paid in country $c$ for good $g .{ }^{17}$ Using this measure of prices, we estimate the following specification

$$
\log \left(\text { price }_{c g}\right)=\alpha+\beta \text { Inequality }_{c}+\gamma \mathbf{X}_{c g}+\delta_{g}+\epsilon_{c g}
$$

where $\mathbf{X}_{c g}$ is a vector of control variables described in Table 9, including the first moment of the income distribution $\left(C G D P_{c}\right), \epsilon_{c g}$ is an error term and $\delta_{g}$ are product fixed effects that control for systematic product differences. Errors are clustered at the country level.

Inequality is our measure of income inequality. In the benchmark results, we use the Gini coefficient $\left(G i n i_{c}\right)$, the most commonly used in economic research and the most comprehensive one. Results using further measures of income distribution are shown in section 5.4.

Table 3 shows results for equation 14 for differentiated goods. Results for $\beta$ are positive and significant for all specifications in columns (1) to (7). In our benchmark specification in column (2), the magnitude of the Gini coefficient means that 1 percentage point increase in income inequality leads to an increase in prices of differentiated goods by 0.99 percent. This means that, if we move Gini from a country such as Canada to the US (both similar in income per capita but with roughly 10 percentage points difference in Gini), average export prices increase by roughly $10 \%$.

Results remain significant when adding control variables. Crucially, the sign of the coefficients of control variables are in accordance with the literature on firm heterogeneity and product quality. The interpretation is provided later in this section. ${ }^{18}$

In the theory, we discuss one potential extension to the model that allows for firm heterogeneity. In this case, firms may operate in more than one quality segment. In the presence of product-specific fixed costs and iceberg transportation costs, one can show that export prices increase in income inequality of the destination country, even within the same exporting firm. To investigate this prediction, we estimate the following specification:

$$
\log \left(\text { price }_{c g f}\right)=\alpha+\beta \text { Inequality }_{c}+\gamma \mathbf{X}_{c g}+\delta_{g f}+\epsilon_{c g f},
$$

where $\delta_{g f}$ are firm-product fixed effects, with errors clustered at the country level.

Results are shown in Table 4 for differentiated goods. Also within firms, $\beta$ is positive and significant in all specifications, though results are smaller in magnitudes in comparison to results reported in Table 3. In the benchmark specification from column (2) in Tables 3

\footnotetext{
${ }^{17}$ In results available upon request, we estimate the empirical specification in equation 14 using prices weighted by firm sales. Results in this case are always larger in magnitudes.

${ }^{18}$ Besides the control variables reported in Table 3, we also investigate further control variables such as governance indicators and the level of corruption in the destination country, since higher prices could reflect a premium for risky exports. Results remain significant when adding further control variables.
} 
and 4 , a comparison of $\beta$ 's reveals that the effect within firms $(0.44 \%)$ is much smaller than the effect across firms $(0.99 \%)$, which is consistent with the fact that firms are heterogeneous and produce different levels of product quality. Though the channel we propose in the theory is product quality, in particular our within-firm results may also suggest markup adjustments across destinations. As discussed in the extension to our theory, markups are increasing in quality. Crucially, quality variation is high even within an 8-digit product (our unit of variation), and therefore we can not disentangle the two effects. A 8-digit product is, for instance, a leather shoe covering the ankle. Wihin this category, firms may choose for instance among inputs with varying degrees of quality depending on the production line. A literature on within-firm adjustment has reported substantial product quality variation within the firm. ${ }^{19}$

Control variables: Results for differentiated goods in Tables 3 and 4 are consistent with the mechanism from our theoretical model when there are individuals above and below the income threshold. Results for the control variables are in accordance with the predictions from the literature on product quality. Our results for distance $\left(\right.$ Dist $\left._{c}\right)$ suggest that, with per unit transaction costs, the relative price of the high quality products decreases with distance (Alchian and Allen 1964). Thus, the highest quality is shipped to more distant countries. ${ }^{20}$ The prediction for market size $\left(G D P_{c}\right)$ may be related to the toughness of the market: as the market grows, competition gets tougher and leads to lower prices. ${ }^{21}$

The predicted income effect for differentiated goods can not be explained only by higher markups because of greater market power, since Mktshare $_{f c g}$ (in column (3)) controls for the firm's market share, as also discussed in Manova and Zhang (2012). To minimize concerns with the correlation between market share and prices, we use alternative measures to control for market power, reported in columns (4) and (5). The coefficient for income inequality remains significant in all specifications. Results are also robust controlling for the elasticity of substitution measured by Broda, Greenfield, and Weinstein (2006), added in column (7).

Homogeneous goods: As a first falsification exercise to our results, we investigate the effect of inequality on prices for homogeneous goods. Since these goods do not have scope for vertical differentiation, we do not expect a correlation between prices and inequality. Results in Table 5 show that this is the case. Crucially, for the main control variables, the signs of the coefficients are in accordance with efficiency sorting models such as Melitz (2003) and the opposite when compared to results for differentiated goods (which follow a quality sorting

\footnotetext{
${ }^{19}$ For instance, Verhoogen (2008) and Flach (2014).

${ }^{20}$ In the literature on firm heterogeneity with product quality, more productive firms sell higher quality at higher prices, and only more productive firms are able to reach more distant destinations (see, for instance, Baldwin and Harrigan (2011)).

${ }^{21}$ Firms may also adjust markups: Heterogeneous firms models with linear demand, such as Melitz and Ottaviano (2008), predict that markups decrease as the market sizes increases, since competition gets tougher.
} 
pattern). For the control variable Dist $_{c}$, higher distance implies lower prices. Following the interpretation from efficiency sorting models, only the most productive firms make it to export to distant markets. Since more productive firms have lower marginal costs for their non vertically differentiated products, they charge lower prices. For $G D P_{c}$, when market size grows, average efficiency of firms present in the market decreases and therefore average marginal costs increase, leading to a positive correlation between size and prices.

The fact that our results hold only for differentiated goods and that non-differentiated goods follow a different pattern may be also explained by a cost-competence versus qualitycompetence model, discussed in Eckel, Iacovone, Javorcik, and Neary (2011).

\subsection{Is the effect asymmetric across groups of countries?}

According to Proposition 1, in rich countries where all individuals consume the differentiated good, prices are invariant to changes in inequality. Therefore, we expect the effect of inequality to disappear for these countries. To investigate asymmetries across countries, we divide the destination countries according to the tertiles, quintiles and deciles of income per capita.

Table 6 shows the results for the quintiles of income per capita. Results fit well our theoretical model with exception of the first quintile. We observe that the effect is significant for the second, third and fourth quintiles and not significant for the very poor and very rich countries (in the first and fifth quintiles of the income distribution). Results for the first quintile are driven by extremely poor countries within the sample. A similar pattern is observed for the tertiles, reported in Table 7. Moreover, we also conduct an analysis for the deciles of the income per capita. In results available upon request, we find that results are significant for the second to eighth deciles and therefore, in this case, our model fits well the empirical results with exception of the first decile. ${ }^{22}$

The fact that results are particularly large and significant for middle-income economies is not surprising. Many middle-income economies experienced a sharp increase in the number of upper middle class and rich individuals. With curved income-expansion paths, the new rich will buy proportionately more high quality goods. Moreover, firms may charge even higher markups for these goods: As individuals get wealthier, they tend to devote a higher share of income to brands, luxury, and positional goods, and will be willing to pay higher prices.

In rich countries, increases in inequality are mostly driven by the rise in income of the $20 \%$ wealthiest (i.e., the already rich individuals are getting richer). According to OECD (2011), while real disposable income increased in most OECD countries, the majority of the increase is due to rich individuals, for which income grew faster, therefore widening income

\footnotetext{
${ }^{22}$ Since for the deciles of income a sample split would lead to a very small number of observations, in this case we estimate the effect for the full sample adding dummies.
} 
inequality. ${ }^{23}$

Poverty results: Proposition 3 from our theoretical model does not relate directly to inequality, but rather to poverty rates. To provide more direct evidence for this proposition, we use information on the share of the population below the poverty line. We collect poverty data from the World Bank on the poverty headcount ratio at 1.25 a day $^{24}$, which measures the percentage of the population living on less than 1.25 a day at 2005 international prices. Results reported in Table 7 show that poverty is positively associated with higher prices, but only for poor and middle-income countries. For rich countries the relation is not significant, in accordance with Proposition $3 .^{25}$

\subsection{Effect across products using a continuous measure of product differ- entiation}

We have shown that our results for the first and second moment of the income distribution hold only for differentiated goods. However, the Rauch (1999) classification may be restrictive, and therefore we extend the analysis using a continuous measure of product differentiation. Moreover, the continuous measure is also more closely related to our theoretical framework.

We use the measure of differentiation proposed by Khandelwal (2010), who characterizes industries according to the scope for quality differentiation (Ladders). Industries are classified as long and short quality ladders, i.e., with long and short scope for quality differentiation. We expect the effect of $\mathrm{Gini}_{c}$ on prices to be magnified for sectors classified as high quality ladders, since for these sectors firms can more easily adjust product quality and markups.

Results are shown in Table 8. The interaction term Gini $_{c} *$ Ladders reveals that the effect of income inequality on prices is captured by sectors with high scope for quality differentiation. This result provides further support to the quality and markup hypothesis: For long quality ladders, prices are higher in more unequal destinations.

\footnotetext{
${ }^{23}$ The increase in wealth without an increase in the number of rich individuals in rich countries may be a further reason why we do not find any effect for rich countries, since wealthy individuals are already consumers of high quality products.

${ }^{24}$ Source: http://data.worldbank.org/topic/poverty.

${ }^{25}$ Summary statistics for the poverty headcount ration data follows: Mean value 7.318, standard deviation 9.602 , minimum value 0 and maximum value 84.23. Note that we do not have the same number of observations in comparison to results reported for Gini. The reason is the that poverty data is not available for some countries in our sample and therefore we have a sample of 66,889 observations instead of 82,716 observations for Gini data. Therefore, we only report results for tertiles.
} 


\subsection{Further measures of inequality:}

The Gini $_{c}$ coefficient, the most commonly used in economic research and the most comprehensive one, has several advantages. In particular, it can be easily compared across countries, which is the purpose of this paper, and easily interpreted. It does not depend on the sample or scale used and is versatile across different population groups. However, results based on Gini $_{c}$ might be sensitive to transfers in the middle range, affecting the notion of inequality we want to investigate (in particular, we are interested in the consumption of high quality by high income consumers). One important concern is that the Lorenz curves can have different shapes in different countries that still yield the same Gini $i_{c}$ coefficient. In this case, we would have countries with very different income distributions that still have very similar Gini $_{c}$. Therefore, this section investigates further measures of income inequality, which test whether our results are driven by some peculiarity in the choice of $\operatorname{Gini}_{c}$.

For this purpose, we use quantile ratios and deciles of the distribution. All results in the robustness checks are reported using firm and product fixed effects (within-firm effect, $\delta_{g f}$ ), since results across firms are always higher in magnitudes. In results available upon request, we estimate the effect on prices using only product fixed effects $\left(\delta_{g}\right)$ and report results that are at least $10 \%$ higher in magnitudes.

The analysis of quantile ratios allows us to compare inequality at different points of the distribution. We start by evaluating a widely used measure of inequality, namely the 90:10 ratio (Quantile $90: 10)$. The higher this ratio, the higher the consumption of the richest 10 percent of the population in comparison to the poorest 10 percent of the population. Data for the quantiles come from the UN-WIDER. Results are reported in columns (1), (3) and (5) of Table 12 and are in conformance with the baseline results from Table 6 (results are driven by middle-income countries). However, we are also interested in evaluating which part of the distribution is driving the results. Therefore, we decompose the quantile ratio to evaluate whether results are better explained by inequality among the rich or among the poor individuals.

Therefore, we evaluate inequality in the top of the distribution (given by Quantile $_{c} 90: 50$ ) and in the bottom of the distribution (given by Quantile $_{c} 50: 20$ ). Results are shown in Table 13 and reveal that the positive effect on prices is captured by the top of the distribution of income. This result is consistent with our theoretical mechanism of consumption of high quality. In the theoretical model, the effect on prices is driven by consumption of high quality differentiated goods by richer individuals. Moreover, we have shown conditions under which this effect holds only for middle-income economies. Thus, results in Table 13 are in line with the predictions from the model. 
Finally, we also exploit an interquartile measure referring to the sum of the last two deciles of the income distribution (ninth and tenth deciles), which includes the richest $20 \%$ of the population $\left(\right.$ Decile $\left._{c}\right)$. The underlying idea is that results reported by the Gini coefficient might not capture so well the effects for the tails of the income distribution. The decile groups express the share of total income going to each tenth of the population, ordered according to the size of their income. Results are shown in Table 12 (columns 2, 4 and 6). Results are robust to this measure of inequality.

\subsection{Price dispersion and income inequality:}

Besides evaluating price levels, we ask whether firms ship a more diverse bundle of products for countries with higher income inequality. Therefore, we investigate the effect of inequality on price dispersion. The empirical specification follows:

$$
s t d_{c s f}\left[\ln \left(\text { price }_{c g f}\right)\right]=\alpha+\beta G i n i_{c}+\gamma \mathbf{X}_{c s f}+\delta_{s f}+\epsilon_{c s f},
$$

where $s$ are product subcategories (4-digit product groups) and $s t d_{c s f}\left[\ln \left(\right.\right.$ price $\left.\left._{c g f}\right)\right]$ is the price dispersion in a destination country, measured by the standard deviation of log f.o.b. export prices within a bundle of 4-digit products exported to each destination.

Using equation (16), we calculate price dispersion within each product category by destination market, controlling for firm and sector specific characteristics. Thus, $\beta$ is identified from the variation in price dispersion across destinations. We expect $\beta$ to be positive and significant: The higher the income inequality, the higher the price dispersion $\left(s t d_{c s f}\left[\ln \left(\operatorname{price}_{c g f}\right)\right]\right)$ in the destination market, since firms offer a more diverse bundle of products.

As reported in Table 14, the dispersion in prices is higher in more unequal destination markets. This result can further rationalize the hypothesis from this paper: Demand for multiple quality versions in a country and willingness to pay for quality may explain why exporters produce multiple quality and charge variable markups depending on destination country characteristics. As shown in Table 14, more diverse demand leads to higher price dispersion in a country.

Concerning the control variables, we find that price dispersion is higher in larger markets and in markets in which the firm has a higher market share. On the other hand, price dispersion decreases with distance and with competition (measured by $\ln (N \text { firms })_{c g}$ ). Most likely, firms offer only their most successful varieties in distant and more competitive markets, decreasing price dispersion. For income per capita, results suggest a positive correlation, though the effect is not precisely estimated. 


\subsection{Robustness checks:}

Region/country effects: In order to rule out region or country effects, we exclude the main Brazilian trade partners from the sample at a time. Results are shown in Table 15 in the Appendix: Results are significant when we exclude the United States, Argentina, Mercosur as well as the European Union. Thus, results are not specific to countries or regions in the sample.

Firm selection in the destination country: Results could be driven by self-selection of firms across destination markets with more or less income inequality (though we also show robust results for within-firm price variation across destinations). To show that results are robust despite sorting patterns, in Table 16 we estimate the effect of inequality on export prices only for firms exporting to more than 20 and 30 markets and that export to both developing and developed countries (results in columns (5) to (8)). Moreover, we also report results only for the top 10 destinations of Brazilian products (results for top 10 destinations in terms of number of firms exporting to each destination are shown in columns (1) and (2) and for top 10 destinations in terms of sales, in columns (3) and (4)). Throughout the specifications, the effect of inequality on prices remains statistically significant.

Intra-firm trade: In results available upon request, we use information on the foreign ownership status of the firm in the period 1997-2000 as a proxy for intra-firm trade in the year 2000. Intra-firm trade could bias our price measure and therefore we construct a dummy $F D I_{f}=1$ if the firm has foreign ownership status, and zero otherwise. Using an interaction term $F D I_{f} * G i n i_{c}$ along with $G i n i_{c}$, we show that both coefficients are positive but the effect of $\operatorname{Gini}_{c}$ on prices is not completely captured by the interaction term. Therefore, results are not driven by sales of firms with foreign ownership status.

Composition effects: The different impact of inequality observed for low-, middle- and high-income countries might be due to a composition effect: Brazil may export on average products with large quality ladders to middle income countries and more homogeneous products to low- and high-income countries. To rule out this hypothesis, we show that the mean quality ladder (which refers to the degree of product differentiation) is very similar across income groups: The average ladder are 2.03, 2.01 and 1.92 for the first, second and third tertiles of income, respectively, and with similar standard deviations. Therefore, our results cannot be due to composition effects. 


\section{Conclusion}

This paper provides first firm-level evidence on the links between income inequality and export prices. To guide empirical work, we present a theoretical framework based on a demand composition effect and non-homothetic preferences. Individuals have preferences over homogeneous and differentiated goods, with different levels of quality and different prices associated to them. Poor individuals can only afford consumption of necessities, while individuals above a certain income threshold can afford consumption of a continuum of differentiated goods. An increase in income inequality leads to higher average prices, with this effect disappearing for rich enough countries.

Using detailed firm-level data, we show that prices are systematically higher in more unequal destinations and that the effect disappears for rich enough countries. Four additional findings reinforce our results. First, the positive correlation between prices and inequality holds only for differentiated goods, and in particular for products with high scope for quality differentiation (using a continuous measure of product differentiation). Second, results are particularly important for middle income countries and are never significant for the very rich countries. Third, results hold both within and across firms, though results are higher in magnitude across firms, in accordance with the hypothesis of quality differentiation and with the literature on firm heterogeneity. Fourth, our findings are robust to different measures of income inequality, not driven by selection into destinations and hold for both price levels and price dispersion.

Our results suggest that prices increase in inequality of the destination country and that this effect vanishes for rich enough countries. Thus, market-specific quality differerentiation is an important margin of firm-level adjustment and important to explain the patterns of trade. 


\section{References}

Aguiar, M., And M. Bils (2011): "Has Consumption Inequality Mirrored Income Inequality?," NBER Working Paper No. 1680\%.

Alchian, A. A., And W. R. Allen (1964): Exchange and Production: Competition, Coordination and Control. Wadsworth Publishing Company.

Arkolakis, C., And M.-A. Muendler (2011): "The Extensive Margin of Exporting Products: A Firm-level Analysis," University of California, San Diego, mimeo.

Balassa, B. (1964): "The Purchasing-Power Parity Doctrine: A Reappraisal," Journal of Political Economy, 72, 584596.

Baldwin, R., And J. Harrigan (2011): "Zeros, Quality and Space: Trade Theory and Trade Evidence," American Economic Journal: Microeconomics 3, pp. 60-88.

Bastos, P., And J. Silva (2010): "The Quality of a Firm's Exports: Where You Export to Matters," Journal of International Economics, 82(2), 99-111.

Bekkers, E., J. F. Francois, and M. Manchin (2012): "Import Prices, Income, and Inequality," European Economic Review, 56, 848-869.

Broda, C., J. Greenfield, and D. Weinstein (2006): "From Groundnuts to Globalization: A Structural Estimate of Trade and Growth," NBER Working Paper 12512.

Chen, S., and M. Ravallion (2007): "Absolute Poverty Measures for the Developing World, 1981-2004," World Bank Policy Research Working Paper 4211.

Choi, X., D. Hummels, and C. Xiang (2009): "Explaining Import Quality: The Role of the Income Distribution," Journal of International Economics, 77, 265-275.

Dalgin, M., D. Mitra, and V. Trindade (2008): "Inequality, nonhomothetic preferences, and trade: a gravity approach," Southern Economic Journal, 74, 747-774.

Di Comite, F., J.-F. Thisse, and H. Vandenbussche (2014): "Verti-zontal Differentiation in Export Markets," Journal of International Economics, 93, 50-66.

Eckel, C., L. Iacovone, B. Javorcik, and J. P. Neary (2011): "Multi-Product Firms at Home and Away: Cost-Versus Quality-based Competence," University of Oxford.

Fajgelbaum, P. D., G. M. Grossman, and E. Helpman (2011): "Income Distribution, Product Quality, and International Trade," Journal of Political Economy, 119, 721-765. 
Feenstra, R. C., R. E. Lipsey, H. Deng, A. C. Ma, and H. Mo (2005): "World Trade Flows: 1962-2000," NBER Working paper No. 11040.

Flach, L. (2014): "Quality Upgrading and Price Heterogeneity: Evidence from Brazilian Manufacturing Exporters," University of Munich, mimeo.

Flach, L., ANd E. Janeba (2013): "Income Inequality and Export Prices across Countries," CESifo Working Paper 4298.

Flam, H., and E. Helpman (1987): "Vertical Product Differentiation and North-South Trade," American Economic Review, 77(5), 810 - 822.

Francois, J. F., And S. Kaplan (1996): "Aggregate Demand Shifts, Income Distribution, and the Linder Hypothesis," Review of Economics and Statistics, 78(2), 244-250.

Garcia-Marin, A. (2014): "Income Distribution, Quality Sorting and Trade," mimeo, University of California Los Angeles.

Hallak, J. C. (2006): "Product Quality and the Direction of Trade," Journal of International Economics, 68(1), 238-265.

(2010): "A Product-Quality View of The Linder Hypothesis," The Review of Economics and Statistics, 92(3), 453466.

Hallak, J. C., And P. K. Schott (2011): "Estimating Cross-Country Differences in Product Quality," The Quarterly Journal of Economics, 126, 417-474.

Hummels, D., And P. J. Klenow (2005): "The Variety and Quality of a Nation's Exports," American Economic Review, 95(3), 704-723.

Hummels, D., And A. Skiba (2004): "Shipping the Good Apples Out: An Empirical Confirmation of the Alchian-Allen Conjecture," Journal of Political Economy, 112, 1384-1402.

Khandelwal, A. (2010): "The Long and Short (of) Quality Ladders," Review of Economic Studies, 77, 1450-1476.

Kugler, M., and E. Verhoogen (2012): "Prices, Plant Size, and Product Quality," Review of Economic Studies, 79(1), 307-339.

Kuznets, S. (1955): "Economic Growth and Income Inequality," American Economic Review, $45,1-28$.

Latzer, H., and F. Mayneris (2012): "Income Distribution and Vertical Comparative Advantage: Theory and Evidence," IRES Discussion Paper. 
Lubrano, M. (2013): "The Econometrics of Inequality and Poverty, Lecture 4: Lorenz curves, the Gini coefficient and parametric distributions," Manuscript available online at http://www.vcharite.univ-mrs.fr/PP/lubrano/poverty.htm.

Manova, K., And Z. Zhang (2012): "Export Prices and Heterogeneous Firms Models," Quarterly Journal of Economics, 127, 379-436.

MARKusen, J. (2013): "Putting per-capita income back into trade theory," Journal of International Economics, 90, 255-265.

Martin, J. (2012): "Markups, Quality, and Transport Costs," European Economic Review, $56,777-791$.

Melitz, M. J. (2003): "The Impact of Trade on Intra-Industry Reallocations and Aggregate Industry Productivity," Econometrica, Econometric Society, 71(6), 1695-1725.

Melitz, M. J., And G. I. P. Ottaviano (2008): "Market Size, Trade, and Productivity," Review of Economic Studies, 75(1), 295-316.

Mitra, D., and V. Trindade (2005): "Inequality and Trade," Canadian Journal of Economics, 38(4), 1253-71.

OECD (2011): An Overview of Growing Income Inequalities in OECD Countries: Main Findings. In: Divided We Stand - Why Inequality Keeps Rising.

Ord, J. K. O., G. P. Patil, and C. Taillie (1983): "Truncated Distributions and Measures of Income Inequality," The Indian Journal of Statistics, Series B, 45(3), 413-430.

RAUCH, J. E. (1999): "Networks Versus Markets In International Trade," Journal of International Economics, 48, 7-35.

Samuelson, P. A. (1964): "Theoretical Notes on Trade Problems," The Review of Economics and Statistics, 46 (2), 145154.

Simonovska, I. (2013): "Income Differences and Prices of Tradables," NBER Working Paper 16233.

Verhoogen, E. A. (2008): "Trade, Quality Upgrading and Wage Inequality in the Mexican Manufacturing Sector," The Quarterly Journal of Economics, 123(2), 489-530.

Yurko, A. (2011): "How Does Income Inequality Affect Market Outcomes in Vertically Differentiated Markets?," International Journal of Industrial Organization, 29, 493-503. 
Table 1: Variation in export prices - standard deviation

\begin{tabular}{|c|c|c|c|c|c|}
\hline & Obs & Mean & Std. Dev. & Min & Max \\
\hline \multicolumn{6}{|c|}{$\begin{array}{l}\text { Variation in export prices across destinations within firm-product pairs } \\
\text { Standard deviation of prices across destinations: }\end{array}$} \\
\hline Total trade & 54619 & 0.1073 & 0.2180 & 0 & 1.5677 \\
\hline Differentiated goods & 45271 & 0.1099 & 0.2201 & 0 & 1.5677 \\
\hline Homogeneous goods & 1203 & 0.0607 & 0.1331 & 0 & 1.0653 \\
\hline \multicolumn{6}{|c|}{$\begin{array}{l}\text { Variation in export prices across firms within country-product pairs } \\
\text { Standard deviation of prices across firms: }\end{array}$} \\
\hline Total trade & 43525 & 0.2106 & 0.3211 & 0 & 1.5955 \\
\hline \multirow{2}{*}{ Differentiated goods } & 34314 & 0.2268 & 0.3282 & 0 & 1.5955 \\
\hline & 5304 & 0.1097 & 0.2476 & 0 & 1.5301 \\
\hline Homogeneous goods & 924 & 0.1048 & 0.2089 & 0 & 1.5032 \\
\hline
\end{tabular}

Table 2: Main explanatory variables, according to the tertile of the income distribution

\begin{tabular}{|c|c|c|c|c|c|}
\hline Variable & Mean & Std. Dev. & Min. & Max. & $\mathbf{N}$ \\
\hline \multicolumn{6}{|c|}{ First tertile of the distribution of $C G D P_{c}$} \\
\hline$G D P_{c}$ & $329,513,308$ & $1,003,365,021$ & $2,606,171$ & $5,052,199,936$ & 31 \\
\hline$C G D P_{c}$ & $2,635.498$ & $1,383.968$ & 513.906 & $4,732.128$ & 31 \\
\hline Dist $_{c}$ & $8,881.426$ & $4,478.001$ & $2,380.92$ & $18,396.479$ & 31 \\
\hline Gini $_{c}$ & 44.687 & 9.625 & 26 & 62.5 & 31 \\
\hline \multicolumn{6}{|c|}{ Second tertile of the distribution of $C G D P_{c}$} \\
\hline$G D P_{c}$ & $198,419,970$ & $283,274,398$ & $2,040,752$ & $1,352,476,032$ & 30 \\
\hline$C G D P_{c}$ & $8,201.286$ & $2,102.586$ & $4,753.42$ & $11,430.188$ & 30 \\
\hline Dist $_{c}$ & $8,400.192$ & $4,163.122$ & $1,134.65$ & $16,409.975$ & 30 \\
\hline$G i n i_{c}$ & 42.53 & 10.179 & 24.3 & 57.8 & 30 \\
\hline \multicolumn{6}{|c|}{ Third tertile of the distribution of $C G D P_{c}$} \\
\hline$G D P_{c}$ & $714,360,206$ & $1,786,852,465$ & $5,536,964$ & $9764,800,512$ & 30 \\
\hline$C G D P_{c}$ & $24,095.87$ & $6,835.66$ & $13,616.582$ & $48,217.272$ & 30 \\
\hline Dist $_{c}$ & $10,338.795$ & $2,393.837$ & $6,343.316$ & $18,821.258$ & 29 \\
\hline Gini $_{c}$ & 32.767 & 6.627 & 24.8 & 57.5 & 30 \\
\hline
\end{tabular}

Figure 1: Gini and income per capita for different tertiles of income per capita
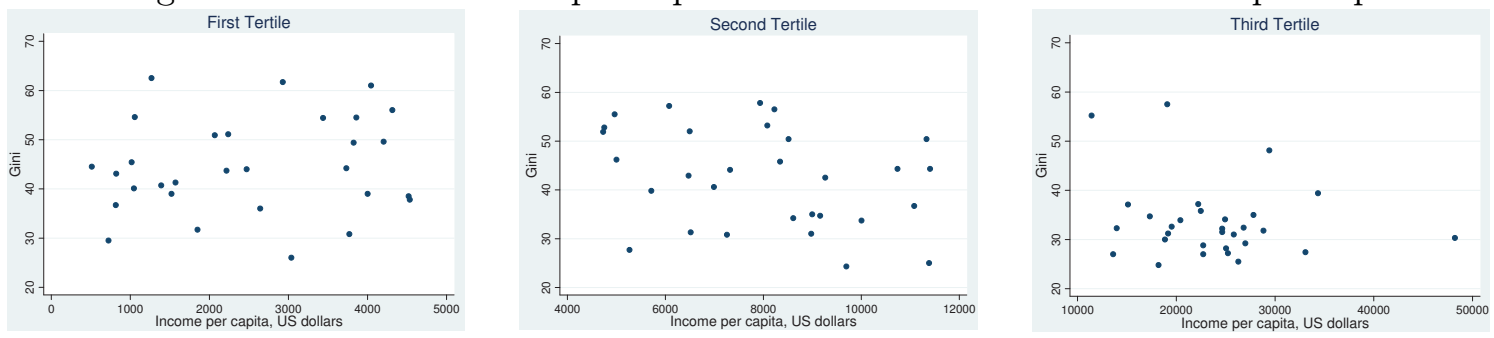
Table 3: Export prices within product pairs across firms and countries for Differentiated goods

\begin{tabular}{|c|c|c|c|c|c|c|c|}
\hline $\begin{array}{r}\text { Dependent variable: } \\
\ln (\text { price })_{c g}\end{array}$ & (1) & (2) & (3) & (4) & $(5)$ & (6) & (7) \\
\hline Gini $_{c}$ & $\begin{array}{c}0.00556^{* * *} \\
(0.000933)\end{array}$ & $\begin{array}{c}0.00990^{* * *} \\
(0.00103)\end{array}$ & $\begin{array}{l}0.0101^{* * *} \\
(0.00103)\end{array}$ & $\begin{array}{c}0.00854^{* * *} \\
(0.00108)\end{array}$ & $\begin{array}{c}0.00850^{* * *} \\
(0.00108)\end{array}$ & $\begin{array}{c}0.00981^{* * * *} \\
(0.00104)\end{array}$ & $\begin{array}{c}0.00990^{* * *} \\
(0.00103)\end{array}$ \\
\hline $\ln (G D P)_{c}$ & & $\begin{array}{c}-0.0128^{* *} \\
(0.00534)\end{array}$ & $\begin{array}{c}-0.0101^{*} \\
(0.00575)\end{array}$ & $\begin{array}{c}-0.0321 * * * \\
(0.00659)\end{array}$ & $\begin{array}{c}-0.0317^{* * *} \\
(0.00660)\end{array}$ & $\begin{array}{c}-0.0141^{* *} \\
(0.00623)\end{array}$ & $\begin{array}{c}-0.0127^{* *} \\
(0.00534)\end{array}$ \\
\hline $\ln (C G D P)_{c}$ & & $\begin{array}{l}0.0290^{* *} \\
(0.0125)\end{array}$ & $\begin{array}{l}0.0305^{* *} \\
(0.0126)\end{array}$ & $\begin{array}{l}0.00952 \\
(0.0138)\end{array}$ & $\begin{array}{c}0.0107 \\
(0.0138)\end{array}$ & $\begin{array}{l}0.0283^{* *} \\
(0.0127)\end{array}$ & $\begin{array}{l}0.0288^{* *} \\
(0.0125)\end{array}$ \\
\hline $\ln (\text { Dist })_{c}$ & & $\begin{array}{c}0.0965^{* * *} \\
(0.0137)\end{array}$ & $\begin{array}{c}0.0852^{* * *} \\
(0.0159)\end{array}$ & $\begin{array}{c}0.0884^{* * *} \\
(0.0144)\end{array}$ & $\begin{array}{c}0.0884^{* * *} \\
(0.0144)\end{array}$ & $\begin{array}{c}0.103^{* * *} \\
(0.0198)\end{array}$ & $\begin{array}{c}0.0964^{* * *} \\
(0.0137)\end{array}$ \\
\hline Mktshare fcg & & & $\begin{array}{c}0.0396 \\
(0.0299)\end{array}$ & & & & \\
\hline ShareImp $p_{c, s}$ & & & & $\begin{array}{c}1.161 \\
(1.311)\end{array}$ & & & \\
\hline ShareExp $p_{c, s}$ & & & & & $\begin{array}{l}-0.903 \\
(1.070)\end{array}$ & & \\
\hline $\ln (N \text { firms })_{c g}$ & & & & & & $\begin{array}{l}0.00699 \\
(0.0139)\end{array}$ & \\
\hline $\operatorname{Sigma}_{c, s}$ & & & & & & & $\begin{array}{c}0.000159 \\
(0.000157)\end{array}$ \\
\hline Constant & $\begin{array}{r}2.322^{* * *} \\
(0.0428)\end{array}$ & $\begin{array}{c}1.281^{* * *} \\
(0.174)\end{array}$ & $\begin{array}{c}1.281^{* * *} \\
(0.174)\end{array}$ & $\begin{array}{c}1.919^{* * *} \\
(0.198)\end{array}$ & $\begin{array}{c}1.910^{* * *} \\
(0.197)\end{array}$ & $\begin{array}{c}1.260^{* * *} \\
(0.180)\end{array}$ & $\begin{array}{c}1.282^{* * *} \\
(0.174)\end{array}$ \\
\hline Product FE & $\mathrm{Y}$ & $\mathrm{Y}$ & $\mathrm{Y}$ & $\mathrm{Y}$ & $\mathrm{Y}$ & $\mathrm{Y}$ & $\mathrm{Y}$ \\
\hline Observations & 27,172 & 27,172 & 27,172 & 24,469 & 24,469 & 27,172 & 27,172 \\
\hline R-squared & 0.894 & 0.895 & 0.895 & 0.895 & 0.895 & 0.895 & 0.895 \\
\hline
\end{tabular}

Table 4: Export prices within firm-product pairs across countries for Differentiated goods

\begin{tabular}{|c|c|c|c|c|c|c|c|}
\hline $\begin{array}{r}\text { Dependent variable: } \\
\ln (\text { price })_{f c g}\end{array}$ & (1) & (2) & (3) & (4) & (5) & (6) & (7) \\
\hline Gini $_{c}$ & $\begin{array}{l}0.00194^{* *} \\
(0.000826)\end{array}$ & $\begin{array}{c}0.00444^{* * *} \\
(0.00112)\end{array}$ & $\begin{array}{c}0.00507^{* * *} \\
(0.00112)\end{array}$ & $\begin{array}{c}0.00354^{* * *} \\
(0.00113)\end{array}$ & $\begin{array}{c}0.00346^{* * *} \\
(0.00113)\end{array}$ & $\begin{array}{c}0.00399^{* * *} \\
(0.00111)\end{array}$ & $\begin{array}{c}0.00444^{* * *} \\
(0.00112)\end{array}$ \\
\hline $\ln (G D P)_{c}$ & & $\begin{array}{c}-0.0218^{* * * *} \\
(0.00595)\end{array}$ & $\begin{array}{c}-0.0169^{* * * *} \\
(0.00601)\end{array}$ & $\begin{array}{c}-0.0278^{* * *} \\
(0.00667)\end{array}$ & $\begin{array}{c}-0.0288^{* * *} \\
(0.00663)\end{array}$ & $\begin{array}{c}-0.0282^{* * *} \\
(0.00621)\end{array}$ & $\begin{array}{c}-0.0216^{* * *} \\
(0.00596)\end{array}$ \\
\hline $\ln (C G D P)_{c}$ & & $\begin{array}{c}0.0456^{* * *} \\
(0.0161)\end{array}$ & $\begin{array}{c}0.0482^{* * *} \\
(0.0161)\end{array}$ & $\begin{array}{l}0.0316^{*} \\
(0.0164)\end{array}$ & $\begin{array}{l}0.0310^{*} \\
(0.0164)\end{array}$ & $\begin{array}{c}0.0426^{* * *} \\
(0.0162)\end{array}$ & $\begin{array}{c}0.0452^{* * *} \\
(0.0161)\end{array}$ \\
\hline $\ln (\text { Dist })_{c}$ & & $\begin{array}{c}0.0478^{* * *} \\
(0.0135)\end{array}$ & $\begin{array}{l}0.0275^{*} \\
(0.0141)\end{array}$ & $\begin{array}{c}0.0466^{* * *} \\
(0.0139)\end{array}$ & $\begin{array}{c}0.0477^{* * *} \\
(0.0139)\end{array}$ & $\begin{array}{c}0.0764^{* * *} \\
(0.0168)\end{array}$ & $\begin{array}{c}0.0473^{* * * *} \\
(0.0135)\end{array}$ \\
\hline Mktshare $_{f c g}$ & & & $\begin{array}{c}0.122^{* * *} \\
(0.0262)\end{array}$ & & & & \\
\hline ShareImp $p_{c, s}$ & & & & $\begin{array}{l}-1.680 \\
(1.094)\end{array}$ & & & \\
\hline ShareExp $p_{c, s}$ & & & & & $\begin{array}{l}-0.544 \\
(1.026)\end{array}$ & & \\
\hline $\ln (\text { Nfirms })_{c g}$ & & & & & & $\begin{array}{c}0.0275^{* * *} \\
(0.0106)\end{array}$ & \\
\hline$S_{i g m a} a_{c, s}$ & & & & & & & $\begin{array}{c}0.000129 \\
(0.000218)\end{array}$ \\
\hline Constant & $\begin{array}{c}2.898^{* * *} \\
(0.0385)\end{array}$ & $\begin{array}{c}2.387^{* * *} \\
(0.206)\end{array}$ & $\begin{array}{c}2.375^{* * *} \\
(0.206)\end{array}$ & $\begin{array}{c}2.637^{* * *} \\
(0.223)\end{array}$ & $\begin{array}{c}2.648^{* * *} \\
(0.223)\end{array}$ & $\begin{array}{c}2.264^{* * *} \\
(0.212)\end{array}$ & $\begin{array}{c}2.391^{* * *} \\
(0.206)\end{array}$ \\
\hline Firm-product FE & $\mathrm{Y}$ & $\mathrm{Y}$ & $\mathrm{Y}$ & $\mathrm{Y}$ & $\mathrm{Y}$ & $\mathrm{Y}$ & $\mathrm{Y}$ \\
\hline Observations & 82,716 & 82,716 & 82,716 & 73,766 & 73,766 & 82,716 & 82,716 \\
\hline R-squared & 0.926 & 0.926 & 0.926 & 0.928 & 0.928 & 0.926 & 0.926 \\
\hline
\end{tabular}

NOTES: The standard errors (in parentheses) are clustered at the country level. R-squared includes firm-product FE. 
Table 5: Export prices within firm-product pairs across countries for Homogeneous goods

\begin{tabular}{|c|c|c|c|c|c|c|c|}
\hline $\begin{array}{r}\text { Dependent variable: } \\
\ln (\text { price })_{f c a}\end{array}$ & (1) & $(2)$ & (3) & (4) & (5) & (6) & (7) \\
\hline Gini $_{c}$ & $\begin{array}{l}0.000149 \\
(0.00185)\end{array}$ & & $\begin{array}{l}0.000149 \\
(0.00185)\end{array}$ & $\begin{array}{l}0.000165 \\
(0.00187)\end{array}$ & $\begin{array}{l}0.000208 \\
(0.00197)\end{array}$ & $\begin{array}{l}0.000321 \\
(0.00196)\end{array}$ & $\begin{array}{l}-0.000260 \\
(0.00195)\end{array}$ \\
\hline $\ln (C G D P)_{c}$ & & & $\begin{array}{l}0.00591 \\
(0.0159)\end{array}$ & $\begin{array}{l}0.00566 \\
(0.0155)\end{array}$ & $\begin{array}{r}-0.00481 \\
(0.0171)\end{array}$ & $\begin{array}{r}-0.00303 \\
(0.0167)\end{array}$ & $\begin{array}{l}0.00828 \\
(0.0158)\end{array}$ \\
\hline $\ln (D i s t)_{c}$ & & $\begin{array}{c}-0.0723^{* *} \\
(0.0314)\end{array}$ & $\begin{array}{c}-0.0718^{* *} \\
(0.0341)\end{array}$ & $\begin{array}{c}-0.0711^{* *} \\
(0.0343)\end{array}$ & $\begin{array}{c}-0.0613^{*} \\
(0.0346)\end{array}$ & $\begin{array}{c}-0.0615^{*} \\
(0.0346)\end{array}$ & $\begin{array}{c}-0.0798^{* *} \\
(0.0346)\end{array}$ \\
\hline $\ln (G D P)_{c}$ & & $\begin{array}{c}0.0185^{* * *} \\
(0.00613)\end{array}$ & $\begin{array}{c}0.0175^{* * *} \\
(0.00600)\end{array}$ & $\begin{array}{c}0.0172^{* * * *} \\
(0.00653)\end{array}$ & $\begin{array}{c}0.00803 \\
(0.00600)\end{array}$ & $\begin{array}{c}0.00818 \\
(0.00586)\end{array}$ & $\begin{array}{r}0.0208^{* * *} \\
(0.00714)\end{array}$ \\
\hline Mktshare $_{f c g}$ & & & & $\begin{array}{c}-0.00724 \\
(0.0514)\end{array}$ & & & \\
\hline ShareImp $p_{c, s}$ & & & & & $\begin{array}{l}-0.428 \\
(1.285)\end{array}$ & & \\
\hline Share $\operatorname{Exp}_{c, s}$ & & & & & & $\begin{array}{c}-1.062^{* *} \\
(0.536)\end{array}$ & \\
\hline $\ln (N \text { firms })_{c g}$ & & & & & & & $\begin{array}{l}-0.0169 \\
(0.0129)\end{array}$ \\
\hline Constant & & $\begin{array}{c}5.343 * * * \\
(0.277)\end{array}$ & $\begin{array}{c}5.298^{* * *} \\
(0.374)\end{array}$ & $\begin{array}{c}5.300^{* * * *} \\
(0.374)\end{array}$ & $\begin{array}{c}5.514^{* * *} \\
(0.383)\end{array}$ & $\begin{array}{c}5.491^{* * * *} \\
(0.385)\end{array}$ & $\begin{array}{c}5.332^{* * * *} \\
(0.377)\end{array}$ \\
\hline Firm-product FE & $\mathrm{Y}$ & $\mathrm{Y}$ & $\mathrm{Y}$ & $\mathrm{Y}$ & $\mathrm{Y}$ & $\mathrm{Y}$ & $\mathrm{Y}$ \\
\hline Observations & 2,107 & 2,107 & 2,107 & 2,107 & 1,872 & 1,872 & 2,107 \\
\hline R-squared & 0.983 & 0.983 & 0.983 & 0.983 & 0.984 & 0.984 & 0.983 \\
\hline
\end{tabular}

NOTES: The standard errors (in parentheses) are clustered at the country level. R-squared includes firm-product FE.

Table 6: Export prices within firm-product pairs across countries for the quintiles of the income per capita

\begin{tabular}{rccccc}
\hline Dependent variable: & $\begin{array}{c}\text { First } \\
\text { quintile } \\
(1)\end{array}$ & $\begin{array}{c}\text { Second } \\
\text { quintile } \\
(2)\end{array}$ & $\begin{array}{c}\text { Third } \\
\text { quintile } \\
(\text { price })_{f c g}\end{array}$ & $\begin{array}{c}\text { Fourth } \\
\text { quintile } \\
(4)\end{array}$ & $\begin{array}{c}\text { Fifth } \\
\text { quintile } \\
(5)\end{array}$ \\
\hline Gini $_{c}$ & -0.164 & $0.00750^{* *}$ & $0.0259^{* *}$ & $0.00611^{* *}$ & 0.00222 \\
& $(0.186)$ & $(0.00336)$ & $(0.0106)$ & $(0.00286)$ & $(0.0102)$ \\
$\ln (G D P)_{c}$ & $-0.121^{*}$ & -0.0423 & $-0.323^{* * *}$ & $-0.0268^{* *}$ & -0.0398 \\
& $(0.0661)$ & $(0.0261)$ & $(0.0947)$ & $(0.0115)$ & $(0.0288)$ \\
$\ln (C G D P)_{c}$ & 1.045 & 0.0725 & 0.0188 & 0.0981 & 0.331 \\
& $(1.163)$ & $(0.122)$ & $(0.156)$ & $(0.174)$ & $(0.338)$ \\
$\ln (\text { Dist })_{c}$ & -1.497 & 0.0141 & 0.201 & $0.0776^{* *}$ & -0.0861 \\
& $(1.888)$ & $(0.0589)$ & $(0.141)$ & $(0.0395)$ & $(0.200)$ \\
\hline Firm-product FE & $\mathrm{Y}$ & $\mathrm{Y}$ & $\mathrm{Y}$ & $\mathrm{Y}$ & $\mathrm{Y}$ \\
Constant & $\mathrm{Y}$ & $\mathrm{Y}$ & $\mathrm{Y}$ & $\mathrm{Y}$ & $\mathrm{Y}$ \\
Observations & 7,792 & 13,874 & 8,642 & 36,182 & 16,226 \\
R-squared & 0.979 & 0.957 & 0.980 & 0.959 & 0.966 \\
\hline
\end{tabular}

NOTES: The standard errors (in parentheses) are clustered at the country level.

R-squared includes firm-product FE. 
Table 7: Export prices within firm-product pairs for the tertiles of the income per capita: Poverty versus Gini

\begin{tabular}{|c|c|c|c|c|c|c|}
\hline \multirow{2}{*}{$\begin{array}{r}\text { Dependent variable: } \\
\ln (\text { uprice })_{f c g}\end{array}$} & \multicolumn{2}{|c|}{ First Tertile } & \multicolumn{2}{|c|}{ Second Tertile } & \multicolumn{2}{|c|}{ Third Tertile } \\
\hline & (1) & $(2)$ & $(3)$ & $(4)$ & $(5)$ & $(6)$ \\
\hline Gini $_{c}$ & $\begin{array}{l}-0.00215 \\
(0.00473)\end{array}$ & & $\begin{array}{l}0.00431^{* *} \\
(0.00209)\end{array}$ & & $\begin{array}{l}0.000762 \\
(0.00556)\end{array}$ & \\
\hline $\ln (\text { Poverty }, 1.25 \$)_{c}$ & & $\begin{array}{l}0.142^{* *} \\
(0.0665)\end{array}$ & & $\begin{array}{c}0.0626^{* * *} \\
(0.0176)\end{array}$ & & $\begin{array}{r}-0.00352 \\
(0.0433)\end{array}$ \\
\hline $\ln (C G D P)_{c}$ & $\begin{array}{l}0.165^{* *} \\
(0.0745)\end{array}$ & $\begin{array}{l}0.184^{* *} \\
(0.0814)\end{array}$ & $\begin{array}{l}0.00812 \\
(0.0649)\end{array}$ & $\begin{array}{c}0.0188 \\
(0.0201)\end{array}$ & $\begin{array}{c}0.201 \\
(0.122)\end{array}$ & $\begin{array}{c}0.142 \\
(0.105)\end{array}$ \\
\hline $\ln (\text { Dist })_{c}$ & $\begin{array}{l}0.0990^{*} \\
(0.0530)\end{array}$ & $\begin{array}{l}0.188^{* *} \\
(0.0768)\end{array}$ & $\begin{array}{r}0.0648^{* *} \\
(0.0273)\end{array}$ & $\begin{array}{r}0.147^{* * *} \\
(0.0306)\end{array}$ & $\begin{array}{l}-0.0965 \\
(0.152)\end{array}$ & $\begin{array}{l}-0.0276 \\
(0.0263)\end{array}$ \\
\hline $\ln (G D P)_{c}$ & $\begin{array}{c}-0.0907^{* * * *} \\
(0.0260)\end{array}$ & $\begin{array}{c}-0.0394 \\
(0.154)\end{array}$ & $\begin{array}{c}-0.0450^{* * *} \\
(0.0120)\end{array}$ & $\begin{array}{c}-0.106^{* * *} \\
(0.0205)\end{array}$ & $\begin{array}{l}-0.0206 \\
(0.0227)\end{array}$ & $\begin{array}{l}-0.468^{*} \\
(0.271)\end{array}$ \\
\hline Mktshare $_{f c g}$ & & & & & & \\
\hline Firm-product FE & $\mathrm{Y}$ & $\mathrm{Y}$ & $\mathrm{Y}$ & $\mathrm{Y}$ & $\mathrm{Y}$ & $\mathrm{Y}$ \\
\hline Constant & $\mathrm{Y}$ & $\mathrm{Y}$ & $\mathrm{Y}$ & $\mathrm{Y}$ & $\mathrm{Y}$ & $\mathrm{Y}$ \\
\hline Observations & 18,290 & 12,216 & 43,328 & 29,866 & 21,098 & 11,973 \\
\hline R-squared & 0.953 & 0.960 & 0.947 & 0.944 & 0.959 & 0.963 \\
\hline
\end{tabular}

Table 8: Export prices using a continuous measure of product differentiation Ladders $s_{s}$

\begin{tabular}{rccc}
\hline Dependent variable: & $(1)$ & $(2)$ & $(3)$ \\
$\ln \left(\right.$ price $_{f c g}$ & & & $0.00130^{*}$ \\
& & & $(0.000668)$ \\
Ladder $_{s} *$ Fini $_{c}$ & $0.00129^{*}$ & $0.00124^{*}$ & -0.00115 \\
& $(0.000665)$ & $(0.000667)$ & $(0.00142)$ \\
$\ln (\text { CGDP })_{c}$ & $(0.00129)$ & $(0.00142)$ & 0.0155 \\
& & 0.0150 & $(0.0113)$ \\
$\ln (\text { Dist })_{c}$ & $0.0362^{* * *}$ & $(0.0113)$ & $0.0367^{* * *}$ \\
& $(0.00779)$ & $(0.00902)$ & $(0.00959)$ \\
$\ln (\text { GDP })_{c}$ & $-0.00902^{* * *}$ & $-0.0127^{* * *}$ & $-0.0113^{* * *}$ \\
& $(0.00309)$ & $(0.00406)$ & $(0.00414)$ \\
$M k t s h a r e_{f c g}$ & & & $0.0345^{*}$ \\
& & & $(0.0179)$ \\
Constant & $3.108^{* * *}$ & $2.957^{* * *}$ & $2.956^{* * *}$ \\
& $(0.0902)$ & $(0.145)$ & $(0.145)$ \\
\hline Firm-product FE & $\mathrm{Y}$ & $\mathrm{Y}$ & $\mathrm{Y}$ \\
Observations & 56,222 & 56,222 & 56,222 \\
R-squared & 0.970 & 0.970 & 0.970
\end{tabular}

NOTES: The standard errors (in parentheses) are clustered at the country level.

R-squared includes firm-product FE. 


\section{A Descriptive Statistics}

Table 9: Main control variables $\mathbf{X}_{g f c}$ :

\begin{tabular}{|c|c|}
\hline $\mathbf{x}_{g f c}$ & Variable description \\
\hline \multicolumn{2}{|c|}{ Country characteristics: } \\
\hline$G D P_{c}$ & $G D P$ of country $c$ (measure of country size) \\
\hline Dist $_{c}$ & Distance to country $c$ \\
\hline$C G D P_{c}$ & $G D P$ per capita of $c$ \\
\hline \multicolumn{2}{|c|}{ Firm and market characteristics: } \\
\hline Mktshare $_{g f c}$ & Market share of $f g$ in $c$ with respect to the sum of firms exporting $g$ to $c$ \\
\hline ShareImp $p_{c, s}$ & $\frac{I m p_{c s_{i}}}{i \neq I m p_{c s_{i}}}$. Share of imports of $c$ in sector $s_{i}$ with respect to all sectors $j \neq i$ \\
\hline ShareExp $p_{c, s}$ & $\frac{E x p_{c s}}{\sum_{j \neq i} E x p_{c s_{j}}}$. Share of exports of $c$ in sector $s_{i}$ as proxy for production in $c$ \\
\hline Mktshare $_{f, s}$ & Share of imports in $s_{i}$ from Brazilian firms with respect to total imports from the World \\
\hline Nfirms $s_{g c}$ & Number of Brazilian firms selling $g$ in country $c$ (competition measure) \\
\hline $\operatorname{Sigma}_{c, s}$ & Import demand elasticities at the 3 -digit HS for each country $c$ \\
\hline Ladder $_{s}$ & Degree of vertical differentiation of the product, aggregated to sector $s$ from Khandelwal (2010) \\
\hline
\end{tabular}

\section{B Data Appendix}

\section{B.1 SECEX firm-level data for the year 2000: data construction}

Firms in the SECEX data are identified by the unique CNPJ tax number and products are coded according to the 8-digit NCM Mercosur classification of goods (NCM-SH Nomenclatura Comum do Mercosul, Sistema Harmonizado). The first 6 digits correspond to the international HS classification (Harmonized System). ${ }^{26}$

The Brazilian SECEX exports data contains information on agricultural sector and observations without information on quantities. The procedure to construct the data for the cross-section 2000 follows:

1. If the observation relates to agricultural and mining sector, it was dropped from the sample. The same if the observation refers to commercial intermediates. Thus, only manufacturing firms are considered. This procedure removed 11,192 observations.

2. If the observation contains zero exporting value, it was removed from the sample. As described in Arkolakis and Muendler (2011), these observations correspond to reporting errors or shipments of commercial samples. As in Arkolakis and Muendler (2011), 484 observations are removed.

3. If the observation contains no information on export quantities, it was removed from the sample. This procedure removed 37,903 observations. Without information on quantities,

\footnotetext{
${ }^{26}$ Since the first six digits coincide with the 6-digit HS classification, it is possible to match the HS and NCM classification with the SITC classification (Standard International Trade Classification). Thus, the data can be matched with the Rauch (1999) classification of goods and the NBER-UN World trade data. Moreover, the similarity in classification between NCM and HS allows better comparison to the literature.
} 
it is not possible to construct unit values, defined as $p_{f c g}=\frac{\text { Value }_{f c g}}{\text { Quantity }_{f c g}}$, for $f$ the firm, $g$ the product and $c$ the destination country. Importantly, the lack of information on quantities is not systematic by industry, destination or type of product. Thus, there is no concern with sample selection. ${ }^{27}$

A product $g$ is defined as a NCM 8-digit product. Table 10 shows examples of products at different levels of aggregation.

Table 10: Examples of Products:

\begin{aligned} & \hline Example of 2, 4 and 6-digit products: \\ & 64 Fottwear, gaiters, and the like. \\ & 6401 Waterproof footwear, rubber or plastics, bond sole. \\ & 6402 Footwear, outer sole and upper rubber or plastic nesoi. \\ & 6403 Footwear, outer sole rub, plastic or leather and upper leather. \\ & 6404 Footwear, outer sole rub, plastic or leather and upper tex. \\ & 6405 Footwear nesoi \\ & 640110 Waterproof footwear incorporating a protective metal toe-cap \\ & 640191 Waterproof footwear covering the knee \\ & \hline Further example of 6 and 8-digit products: \\ & $630900 \quad$ Worn clothing and other worn articles. \\ & $63090010 \quad$ Articles of apparel, clothing accessories and parts thereof. \\ & 63090090 Other textile materials, used. \\ & \hline Complete list of NCM 8-digit products available at \\ & http://www.sefaz.mt.gov.br/portal/download/arquivos/Tabela_NCM.pdf. \end{aligned}

Table 11 presents a brief summary of average number of destinations and number of products by firm. Column 2 shows that firms that export to more than 10 destinations export on average 26.29 different NCM 8-digit products. And, from Column 3, firms that export more than 10 products export to 8.77 destinations on average.

Table 11: Average number of destinations and number of products by firm

\begin{tabular}{ccc}
\hline $\begin{array}{c}\text { Average number of products } \\
\text { by number of destinations }\end{array}$ & $\begin{array}{c}\text { Average number of destinations } \\
\text { by number of products exported }\end{array}$ \\
\hline 1 & 2.83 & 1.70 \\
2 & 3.40 & 2.84 \\
3 & 4.25 & 3.84 \\
4 & 5.04 & 4.62 \\
5 & 6.21 & 5.57 \\
$10+$ & 26.29 & 8.77 \\
Average & 4.69 & 1.70 \\
\hline
\end{tabular}

\section{B.2 Methodology for construction of the Gini coefficient:}

We use the income inequality data from the WIID2 UNO-WIDER (United Nations World Institute for Development Economics Research). Although, the data contains many duplicate values and missing values for some countries. In case of duplicate values for a country, we

\footnotetext{
${ }^{27}$ As a robustness check to the results, I reestimate the results after removing extreme unit values. The data trimming removes observations for which the unit value $p_{f c g}$ is either 5 times above or 5 times below the median unit price by product $g$. This second step drops 19,960 observations 5 times above and 18,184 observations 5 times below the median (for all types of goods). Results remain robust
} 
keep the variables that satisfy the following criteria (in this order):

Step 1. Highest quality rating (variable Quality $=1$, otherwise 2, 3 or 4 ). The quality rating in the WIID2 was evaluated according to the following criteria: (a) whether the concepts underlying the observations are known; (b) the coverage of the income/consumption concept; and (c) the survey quality. A observation receives quality rating 1 for observations that satisfy the criteria (a) and (b).

Step 2. Latest Revision. The WIID1 was updated to construct the new WIID2 database, which is the most recent and updated revision.

Step 3. Area covered refers to the whole country (variable AreaCovr $=A l l$ ).

Step 4. Basic statistical unit is the household (variable IncSharU $=$ household, instead of tax unit, person or family).

Step 5. Unit of analysis is the person (variable Uof Anala = person): in this case, the needs of different sized households have been taken into account ${ }^{28}$.

Step 6. Equivalence scale has been adjusted (variable Equivsc $=$ householdpercapita). Since the different sized households have been taken into account, in the equivalence scale the adjustment has been made for the different sized and composed households.

Step 7. Icome definition is disposable income (variable IncDefn $=$ Income, Disposable). This classification is similar to the one from the Canberra Group on Household Income Statistics with the United Nations Statistics Division ${ }^{29}$.

Step 8. Information on currency is available (variable Curref with available information).

Step 9. Income definition is income (variable IncDefn $=$ Income,...).

Step 10. Income definition is gross income (variable IncDefn $=$ Income, Gross).

Step 11. Equivalence scale used was the household (variable

Equivsc $=$ Householdeq, OECDmod).

This methodology leads to 72 unique Gini coefficients (72 countries) ${ }^{30}$. For countries with missing information for the year 2000, we follow the same steps described above for the years 1999 and 2001, respectively. In this way, the final methodology leads to 98 unique Gini coefficients (103 countries) ${ }^{31}$. When we combine the Gini coefficient with the firm-level data, we exclude destination countries with less than 3 observations in the sample. ${ }^{32}$

\footnotetext{
${ }^{28}$ In the case in which the unit of analysis is the household, the size of the households and the needs of different sized households have not been taken into account.

${ }^{29}$ The final report and recommendations from the Canberra Group on household income statistics can be found at http://www.lisproject.org/links/canberra/finalreport.pdf

${ }^{30}$ Only for Finland there were still duplicate values for the year 2000 after all the steps. In this case, the observation was kept if the currency available was in euros curre $f=E U R 02 /$ year

${ }^{31}$ The raw data available at http://www.wider.unu.edu/research/Database/en_GB/wiid/.

${ }^{32}$ Countries with less than three observations are Armenia, Azerbaijan, Laos, Lesotho, Moldova, Uzbekistan, and Georgia.
} 


\section{Robustness checks}

Table 12: Export prices for income tertiles: 90:10 ratio and deciles

\begin{tabular}{rcccccc}
\hline Dependent variable: & \multicolumn{2}{c}{ First Tertile } & \multicolumn{2}{c}{ Second Tertile } & \multicolumn{2}{c}{ Third Tertile } \\
$\ln \left(\right.$ price $_{f c g}$ & $(1)$ & $(2)$ & $(3)$ & $(4)$ & $(5)$ & $(6)$ \\
\hline Quantile $_{c} 90: 10$ & $-0.00246^{*}$ & & $0.00688^{* *}$ & & -0.0408 \\
& $(0.00148)$ & & $(0.00342)$ & & $(0.0360)$ & \\
Deciles $_{c}$ & & -0.00417 & & $0.00477^{* *}$ & & -0.0177 \\
& & $(0.00421)$ & & $(0.00227)$ & & $(0.0143)$ \\
$\ln (C G D P)_{c}$ & $0.159^{* *}$ & $0.220^{* * *}$ & -0.0740 & -0.0655 & -0.241 & -0.294 \\
& $(0.0720)$ & $(0.0716)$ & $(0.0606)$ & $(0.0604)$ & $(0.340)$ & $(0.352)$ \\
$\ln (\text { Dist })_{c}$ & 0.0372 & $0.0782^{*}$ & $0.0546^{* *}$ & $0.0537^{* *}$ & -0.304 & -0.339 \\
& $(0.0570)$ & $(0.0458)$ & $(0.0226)$ & $(0.0223)$ & $(0.406)$ & $(0.408)$ \\
$\ln (G D P)_{c}$ & $-0.0788^{* * *}$ & $-0.0882^{* * *}$ & $-0.0462^{* * *}$ & $-0.0418^{* * *}$ & -0.0588 & -0.0603 \\
& $(0.0203)$ & $(0.0222)$ & $(0.0137)$ & $(0.0122)$ & $(0.0407)$ & $(0.0407)$ \\
& & & & & & \\
\hline Firm-product FE & $\mathrm{Y}$ & $\mathrm{Y}$ & $\mathrm{Y}$ & $\mathrm{Y}$ & $\mathrm{Y}$ & $\mathrm{Y}$ \\
Constant & $\mathrm{Y}$ & $\mathrm{Y}$ & $\mathrm{Y}$ & $\mathrm{Y}$ & $\mathrm{Y}$ & $\mathrm{Y}$ \\
Observations & 19,859 & 19,859 & 41,306 & 41,306 & 9,379 & 9,379 \\
$\mathrm{R}-$-squared & 0.952 & 0.952 & 0.951 & 0.951 & 0.967 & 0.967 \\
\hline
\end{tabular}

1. The standard errors are clustered at the country level.

2. The R-squared reported refer to the LSDV estimator, which includes the firm-product FE.

Table 13: Export prices for income tertiles: Quantile ratios

\begin{tabular}{rcccccc}
\hline Dependent variable: & \multicolumn{2}{c}{ First Tertile } & \multicolumn{2}{c}{ Second Tertile } & \multicolumn{2}{c}{ Third Tertile } \\
$\ln (\text { price })_{f c g}$ & $(1)$ & $(2)$ & $(3)$ & $(4)$ & $(5)$ & $(6)$ \\
\hline Quantile $_{c} 90: 50$ & -0.0174 & & $0.0179^{* *}$ & & -0.202 & \\
& $(0.0132)$ & & $(0.00769)$ & & $(0.160)$ & \\
Quantile $_{c} 50: 20$ & & $-0.0104^{*}$ & & $-0.0968^{* *}$ & & -0.0781 \\
& & $(0.00587)$ & & $(0.0405)$ & & $(0.0653)$ \\
$\$ \ln (\mathrm{CGDP}) \_c \$$ & $0.225^{* * *}$ & $0.147^{* *}$ & -0.0983 & $-0.199^{* *}$ & -0.397 & -0.105 \\
& $(0.0713)$ & $(0.0735)$ & $(0.0627)$ & $(0.0835)$ & $(0.382)$ & $(0.345)$ \\
$\$ \ln (\mathrm{Dist}) \_c \$$ & $0.0810^{*}$ & 0.0305 & $0.0448^{* *}$ & 0.00534 & -0.403 & -0.219 \\
& $(0.0437)$ & $(0.0585)$ & $(0.0218)$ & $(0.0272)$ & $(0.422)$ & $(0.394)$ \\
$\$ \ln (\mathrm{GDP}) \_c \$$ & $-0.0892^{* * *}$ & $-0.0765^{* * *}$ & $-0.0383^{* * *}$ & 0.00627 & -0.0644 & -0.0634 \\
& $(0.0217)$ & $(0.0203)$ & $(0.0112)$ & $(0.0168)$ & $(0.0407)$ & $(0.0410)$ \\
& & & & & & \\
\hline Constant & $\mathrm{Y}$ & $\mathrm{Y}$ & $\mathrm{Y}$ & $\mathrm{Y}$ & $\mathrm{Y}$ & $\mathrm{Y}$ \\
Observations & 19,859 & 19,859 & 41,083 & 41,083 & 9,379 & 9,379 \\
R-squared & 0.952 & 0.952 & 0.952 & 0.952 & 0.967 & 0.967 \\
\hline
\end{tabular}

\section{NOTES:}

1. The standard errors are clustered at the country level.

2. The R-squared reported refer to the LSDV estimator, which includes the firm-product FE. 
Table 14: Price dispersion and income inequality

\begin{tabular}{|c|c|c|c|c|c|c|c|}
\hline $\begin{array}{r}\text { Dependent variable: } \\
s t d_{c s f}\left[\ln \left(\text { price }_{c g f}\right)\right]\end{array}$ & (1) & $(2)$ & (3) & $(4)$ & $(5)$ & (6) & $(7)$ \\
\hline \multirow[t]{2}{*}{ Gini $_{c}$} & $0.00269^{* * *}$ & $0.00146^{* *}$ & $0.00162^{* *}$ & $0.00141^{* *}$ & $0.00147^{* *}$ & $0.00152^{* *}$ & $0.00146^{* *}$ \\
\hline & $(0.000398)$ & $(0.000637)$ & $(0.000640)$ & $(0.000638)$ & $(0.000637)$ & $(0.000637)$ & $(0.000637)$ \\
\hline \multirow[t]{2}{*}{$\ln (C G D P)_{c}$} & & 0.0103 & 0.0103 & 0.00963 & 0.0101 & 0.0102 & 0.0104 \\
\hline & & $(0.00903)$ & $(0.00902)$ & $(0.00905)$ & $(0.00905)$ & $(0.00903)$ & $(0.00904)$ \\
\hline \multirow[t]{2}{*}{$\ln (\text { Dist })_{c}$} & & $-0.109^{* * *}$ & $-0.118^{* * *}$ & $-0.110^{* * *}$ & $-0.110^{* * *}$ & $-0.120 * * *$ & $-0.109^{* * *}$ \\
\hline & & $(0.00788)$ & $(0.00842)$ & $(0.00788)$ & $(0.00790)$ & $(0.0102)$ & $(0.00791)$ \\
\hline \multirow[t]{2}{*}{$\ln (G D P)_{c}$} & & $0.0330 * * *$ & $0.0347^{* * *} *$ & $0.0326^{* * *}$ & $0.0329 * * *$ & $0.0350 * * *$ & $0.0329 * * *$ \\
\hline & & $(0.00357)$ & $(0.00357)$ & $(0.00356)$ & $(0.00356)$ & $(0.00369)$ & $(0.00357)$ \\
\hline Mktshare $_{f c g}$ & & & $\begin{array}{c}0.0486^{* * *} \\
(0.0151)\end{array}$ & & & & \\
\hline ShareImp $p_{c, s}$ & & & & $\begin{array}{l}1.200 \\
(0.751)\end{array}$ & & & \\
\hline ShareExp $p_{c, s}$ & & & & & $\begin{array}{c}0.207 \\
(0.492)\end{array}$ & & \\
\hline $\ln (\text { Nfirms })_{c g}$ & & & & & & $\begin{array}{l}-0.0108^{*} \\
(0.00591)\end{array}$ & \\
\hline $\operatorname{Sigma}_{c, s}$ & & & & & & & $\begin{array}{l}-5.05 \mathrm{e}-05 \\
(0.000133)\end{array}$ \\
\hline Firm-subcategory FE & $\mathrm{Y}$ & $\mathrm{Y}$ & $\mathrm{Y}$ & $\mathrm{Y}$ & $\mathrm{Y}$ & $\mathrm{Y}$ & $\mathrm{Y}$ \\
\hline Constant & $\mathrm{Y}$ & $\mathrm{Y}$ & $\mathrm{Y}$ & $\mathrm{Y}$ & $\mathrm{Y}$ & $\mathrm{Y}$ & $\mathrm{Y}$ \\
\hline Observations & 56,926 & 54,749 & 54,749 & 54,749 & 54,749 & 54,749 & 54,749 \\
\hline R-squared & 0.533 & 0.548 & 0.549 & 0.548 & 0.548 & 0.548 & 0.548 \\
\hline
\end{tabular}

NOTES: 1 . The standard errors are clustered at the country level.

2. The R-squared reported refer to the LSDV estimator, which includes the firm-subcategory FE.

Table 15: Robustness checks: rule out region effects

\begin{tabular}{|c|c|c|c|c|c|c|c|c|}
\hline \multirow{2}{*}{$\begin{array}{r}\text { Dependent variable: } \\
\ln (\text { price }) f c q\end{array}$} & \multicolumn{2}{|c|}{ Without US } & \multicolumn{2}{|c|}{ Without Argentina } & \multicolumn{2}{|c|}{ Without EU } & \multicolumn{2}{|c|}{ Without Mercosur } \\
\hline & $(1)$ & (2) & (3) & $(4)$ & (5) & $(6)$ & $(7)$ & $(8)$ \\
\hline Gini $_{c}$ & $\begin{array}{c}0.00352^{* * *} \\
(0.00113)\end{array}$ & $\begin{array}{c}0.00409^{* * *} \\
(0.00113)\end{array}$ & $\begin{array}{c}0.00351^{* * *} \\
(0.00116)\end{array}$ & $\begin{array}{c}0.00409^{* * *} \\
(0.00116)\end{array}$ & $\begin{array}{c}0.00360^{* * *} \\
(0.00121)\end{array}$ & $\begin{array}{c}0.00425^{* * *} \\
(0.00121)\end{array}$ & $\begin{array}{c}0.00336^{* * *} \\
(0.00120)\end{array}$ & $\begin{array}{c}0.00360^{* * *} \\
(0.00121)\end{array}$ \\
\hline $\ln (C G D P)_{c}$ & $0.0328^{* *}$ & $0.0339^{* *}$ & $0.0458^{* * *}$ & $0.0461 * * *$ & $0.0703^{* * *}$ & $0.0744^{* * *}$ & $0.0458 * * *$ & $0.0460^{* * *}$ \\
\hline $\ln (D i s t)_{c}$ & $\begin{array}{c}(0.0164) \\
0.0467 * * * \\
(0.0138)\end{array}$ & $\begin{array}{c}(0.0164) \\
0.0248^{*} \\
(0.0146)\end{array}$ & $\begin{array}{c}(0.0171) \\
0.0209 \\
(0.0171)\end{array}$ & $\begin{array}{c}(0.0171) \\
-0.0104 \\
(0.0180)\end{array}$ & $\begin{array}{c}(0.0179) \\
0.0713^{* * *} \\
(0.0147)\end{array}$ & $\begin{array}{c}(0.0179) \\
0.0507 * * * \\
(0.0153)\end{array}$ & $\begin{array}{r}(0.0175) \\
-0.00641 \\
(0.0238)\end{array}$ & $\begin{array}{c}(0.0175) \\
-0.0364 \\
(0.0247)\end{array}$ \\
\hline $\ln (G D P)_{c}$ & $-0.0291 * * *$ & $-0.0249 * * *$ & $\begin{aligned} & (0.0171) \\
-0.0182^{* * *} & \end{aligned}$ & $\begin{array}{l}(0.0180) \\
-0.0102\end{array}$ & $\begin{aligned} &(0.0147) \\
&-0.0348^{* * *}\end{aligned}$ & $\begin{array}{c}(0.0153) \\
-0.0303^{* * *}\end{array}$ & $\begin{aligned} &(0.0238) \\
&-0.0189 * * *\end{aligned}$ & -0.0112 \\
\hline & $(0.00659)$ & $(0.00662)$ & $(0.00703)$ & $(0.00714)$ & $(0.00676)$ & $(0.00680)$ & $(0.00716)$ & $(0.00727)$ \\
\hline Mktshare $f c g$ & & $0.128^{* * *}$ & & $0.142^{* * *}$ & & $0.132^{* * *}$ & & $0.137^{* * *}$ \\
\hline & & $(0.0277)$ & & $(0.0282)$ & & $(0.0296)$ & & $(0.0298)$ \\
\hline Firm-product FE & $\mathrm{Y}$ & $\mathrm{Y}$ & $\mathrm{Y}$ & $\mathrm{Y}$ & $\mathrm{Y}$ & $\mathrm{Y}$ & $\mathrm{Y}$ & $\mathrm{Y}$ \\
\hline Constant & Y & Y & Y & $\mathrm{Y}$ & Y & Y & Y & $\mathrm{Y}$ \\
\hline Observations & 74,361 & 74,361 & 68,460 & 68,460 & 72,587 & 72,587 & 59,572 & 59,572 \\
\hline R-squared & 0.928 & 0.928 & 0.929 & 0.929 & 0.931 & 0.931 & 0.931 & 0.931 \\
\hline
\end{tabular}

Table 16: Robustness checks: Self-selection into destination markets

\begin{tabular}{|c|c|c|c|c|c|c|c|c|}
\hline \multirow{2}{*}{$\begin{array}{r}\text { Dep. variable: } \\
\ln \left(\text { price }_{f c g}\right. \\
\text { Gini }_{c}\end{array}$} & \multicolumn{2}{|c|}{$\begin{array}{c}\text { Exports to } \\
\text { top } 10 \text { destinations } \\
(\text { number of firms })^{1}\end{array}$} & \multicolumn{2}{|c|}{$\begin{array}{c}\text { Exports to } \\
\text { top } 10 \text { destinations } \\
\text { (amount of exports) }^{2}\end{array}$} & \multicolumn{2}{|c|}{$\begin{array}{c}\text { Firms in } \\
\text { more than } \\
20 \text { destinations }\end{array}$} & \multicolumn{2}{|c|}{$\begin{array}{c}\text { Firms in } \\
\text { more than } \\
\mathbf{3 0} \text { destinations }\end{array}$} \\
\hline & $\begin{array}{c}0.00757^{* * *} \\
(0.00289)\end{array}$ & $\begin{array}{c}0.00738^{* *} \\
(0.00290)\end{array}$ & $\begin{array}{c}0.00433^{*} \\
(0.00235)\end{array}$ & $\begin{array}{c}0.00476^{* *} \\
(0.00234)\end{array}$ & $\begin{array}{c}0.00647^{* * *} \\
(0.00128)\end{array}$ & $\begin{array}{c}0.00731^{* * *} \\
(0.00129)\end{array}$ & $\begin{array}{c}0.00771^{* * * *} \\
(0.00148)\end{array}$ & $\begin{array}{c}0.00854^{* * *} \\
(0.00149)\end{array}$ \\
\hline $\ln (C G D P)_{c}$ & $\begin{array}{c}0.161 * * * \\
(0.0469)\end{array}$ & $\begin{array}{c}0.159 * * * \\
(0.0470)\end{array}$ & $\begin{array}{c}0.0439 \\
(0.0454)\end{array}$ & $\begin{array}{c}0.0413 \\
(0.0454)\end{array}$ & $\begin{array}{c}0.0735^{* * *} \\
(0.0181)\end{array}$ & $\begin{array}{c}0.0764^{* * *} \\
(0.0181)\end{array}$ & $\begin{array}{c}0.0683^{* * *} \\
(0.0206)\end{array}$ & $\begin{array}{c}0.0713^{* * *} * \\
(0.0207)\end{array}$ \\
\hline $\ln (\text { Dist })_{c}$ & $\begin{array}{c}0.0849 * * * \\
(0.0323)\end{array}$ & $\begin{array}{c}0.0768^{* *} \\
(0.0328)\end{array}$ & $\begin{array}{c}0.0735^{* * *} \\
(0.0275)\end{array}$ & $\begin{array}{c}0.0616^{* *} \\
(0.0288)\end{array}$ & $\begin{array}{c}0.0656^{* * *} \\
(0.0162)\end{array}$ & $\begin{array}{c}0.0429 * * \\
(0.0170)\end{array}$ & $\begin{array}{c}0.0822^{* * *} \\
(0.0190)\end{array}$ & $\begin{array}{c}0.0617^{* * *} \\
(0.0200)\end{array}$ \\
\hline $\ln (G D P)_{c}$ & $\begin{array}{c}-0.0531^{* * *} \\
(0.0132)\end{array}$ & $\begin{array}{c}-0.0509 * * * \\
(0.0133)\end{array}$ & $\begin{array}{l}-0.0293^{*} \\
(0.0161)\end{array}$ & $\begin{array}{l}-0.0242 \\
(0.0164)\end{array}$ & $\begin{array}{c}-0.0315^{* * *} \\
(0.00719)\end{array}$ & $\begin{array}{c}-0.0256^{* * *} \\
(0.00730)\end{array}$ & $\begin{array}{c}-0.0287^{* * *} \\
(0.00822)\end{array}$ & $\begin{array}{c}-0.0235 * * * \\
(0.00831)\end{array}$ \\
\hline Mktshare $_{f c g}$ & & $\begin{array}{c}0.130^{*} \\
(0.0694)\end{array}$ & & $\begin{array}{c}0.118^{*} \\
(0.0616)\end{array}$ & & $\begin{array}{c}0.132^{* * *} \\
(0.0308)\end{array}$ & & $\begin{array}{c}0.117 * * * \\
(0.0340)\end{array}$ \\
\hline Firm-product FE & $\mathrm{Y}$ & $\mathrm{Y}$ & $\mathrm{Y}$ & $\mathrm{Y}$ & $\mathrm{Y}$ & $\mathrm{Y}$ & $\mathrm{Y}$ & $\mathrm{Y}$ \\
\hline Constant & $\mathrm{Y}$ & $\mathrm{Y}$ & $\mathrm{Y}$ & $\mathrm{Y}$ & $\mathrm{Y}$ & $\mathrm{Y}$ & $\mathrm{Y}$ & $\mathrm{Y}$ \\
\hline Observations & 44,612 & 44,612 & 42,292 & 42,292 & 34,093 & 34,093 & 24,523 & 24,523 \\
\hline R-squared & 0.956 & 0.956 & 0.951 & 0.951 & 0.889 & 0.889 & 0.881 & 0.881 \\
\hline
\end{tabular}

NOTES: The standard errors are clustered at the country level.
The R-squared reported refer to the LSDV estimator, which includes the firm-product FE.

1 All firms that export to the top 10 destinations of exporters, measured as the number of firms that export to the destination.

${ }^{2}$ All firms that export to the top 10 destinations of exporters, measured as the amount of exports in US dollars. 